\title{
Highly Soluble 1,4-Diaminoanthraquinone Derivative for Nonaqueous Symmetric Redox Flow Batteries
}

\author{
Pieter Geysens, Yun Li, Ivo Vankelecom, Jan Fransaer, and Koen Binnemans*
}

Cite This: ACS Sustainable Chem. Eng. 2020, 8, 3832-3843

Read Online

ABSTRACT: Nonaqueous redox flow batteries (RFBs) based on redox-active organic molecules are regarded as a promising technology for large-scale grid energy storage. 1,4-Diaminoanthraquinones (DAAQs) are particularly interesting as active species because they can have up to five different electrochemically accessible oxidation states, but their practical usability is limited because of their low solubility in commonly used polar organic solvents. We present a DAAQ derivative, 1,4-bis((2-(2-(2methoxyethoxy)ethoxy)ethyl)amino)anthracene-9,10-dione (MeTEG-DAAQ), which can be synthesized from inexpensive precursors and overcomes this disadvantage of low solubility.

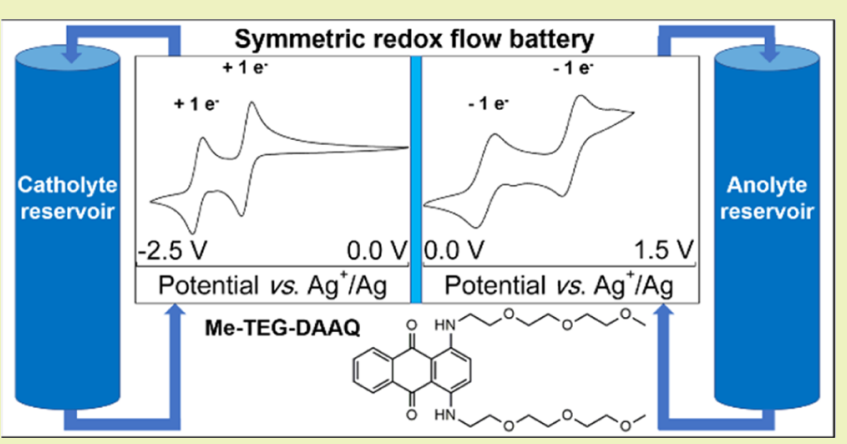
This derivative has a low melting point $\left(25^{\circ} \mathrm{C}\right)$, a concentration exceeding $2.2 \mathrm{~mol} \mathrm{~L}^{-1}$ in the pure state, and is miscible in any ratio with polar organic solvents such as acetonitrile $(\mathrm{MeCN})$ and 1,2 dimethoxyethane. Cyclic voltammetry experiments show that two anodic and two cathodic one-electron redox transitions are electrochemically accessible and highly reversible, with an interval of $1.8 \mathrm{~V}$ between the two inner redox couples and $2.7 \mathrm{~V}$ between the two outer redox couples. Proof-of-concept galvanostatic cycling experiments were conducted on dilute solutions of Me-TEGDAAQ in a simple symmetric electrochemical cell. When only the two inner redox couples are considered, the electrochemical cell can achieve specific capacities close to the theoretical value $\left(2.68 \mathrm{~A} \mathrm{~h} \mathrm{~L}^{-1}\right)$, with only limited capacity fading (i.e., $\left.<20 \%\right)$ over 100 cycles. When the two outer redox couples are considered as well, the cell can achieve its theoretical capacity $\left(5.36 \mathrm{~A} \mathrm{~h} \mathrm{~L}^{-1}\right)$, but faster capacity fading occurs. This combination of high reversibility, high theoretical cell potential (2.7 V), high theoretical energy density $\left(>49 \mathrm{~W} \mathrm{~h} \mathrm{~L}^{-1}\right)$, and limited capacity fading in an electrochemical cell based on one single active species is unprecedented in the RFB literature.

KEYWORDS: all-organic redox flow batteries, anthraquinone dyes, Disperse Blue 134, electrochemical energy storage, molecular radicals, oligo(ethylene glycol) ethers

\section{INTRODUCTION}

To meet the ever-increasing energy demand of our society, technologies that can store energy in a large scale are urgently needed. ${ }^{1}$ Such technologies can be implemented as loadleveling devices in the electrical grid to support renewable energy sources such as wind and solar, which have an inherently intermittent output because of their dependence on weather conditions. ${ }^{2-4}$ Electrochemical energy storage (EES) systems are gaining popularity over more mature technologies such as pumped hydro energy storage and compressed air energy storage because they are not limited by the geographical situation and can achieve higher energy densities. ${ }^{1,5,6}$ In particular, redox flow batteries (RFBs) are regarded as one of the most promising EES technologies. ${ }^{7-11}$

RFBs are distinctly different from other secondary battery technologies such as lithium-ion and lead-acid because they store energy in two separate liquid electrolytes that contain dissolved redox-active species, as opposed to solid electrodes. The electrolytes are pumped from storage tanks to an electrochemical cell where the conversion between electrical and chemical energy occurs. This unique feature is the basis of their main advantage, namely, the decoupling of power and capacity. Because the capacity can be scaled up by increasing the volume of the storage tanks, RFBs are capable of storing grid energy on a multi-megawatt hour scale. ${ }^{12}$ Furthermore, RFBs are durable and flexible systems that have fast response times, deep discharge ability, high stability against fluctuating power supply, and good tolerance against over-(dis)charging. ${ }^{7-12}$ At present, the most developed RFB system is the aqueous all-vanadium RFB (VRB), which uses watersoluble vanadium ions in different oxidation states as redoxactive species. First conceptualized in 1986, this technology

Received: December 4, 2019

Revised: February 7, 2020

Published: February 14, 2020 
still enjoys considerable interest from the research community. ${ }^{13-16}$ The VRB is an example of a symmetric RFB because it uses only one element in both electrolytes. Such symmetric cells have the additional advantage that cross-over of the electrolytes results only in self-discharge of the cell and not in permanent contamination.

One of the major challenges to overcome with RFBs is their inherently lower energy density compared to batteries where the energy is stored in solid electrodes. This issue can be solved by increasing the cell potential and by increasing the concentration of the redox-active species. Therefore, research of new RFB systems is moving toward nonaqueous electrolytes composed of ionic liquids, deep-eutectic solvents, or molecular organic solvents, which usually have a wider electrochemical stability window than water. ${ }^{17-22}$ This increases the number of useable redox couples and allows for higher cell potentials. $^{23-25}$ Furthermore, many organic redox-active compounds have low solubility in water but are highly soluble in organic solvents. This drastically increases the number of active species/solvent combinations that can be explored and thus increases the chance to find a low-cost system with high energy density. Many complexes of transition metals such as ruthenium, ${ }^{26,27}$ vanadium, ${ }^{28}$ iron, ${ }^{29-31}$ chrome, ${ }^{32,33}$ nickel, ${ }^{30}$ cobalt, $^{34}$ and copper ${ }^{35,36}$ with organic ligands have been reported as active species for RFB electrolytes. However, the high cost of some of these metals limits their economic feasibility, and the environmental impact and toxicity of heavy metals must also be considered for large-scale applications such as grid energy storage.

Redox-active organic molecules have an advantage over transition metal complexes because they consist entirely of earth-abundant elements (carbon, hydrogen, nitrogen, and oxygen) and can often be prepared from precursors that are already commercially available in a large scale. Many organic molecules and derivatives thereof have already been investigated as potential redox-active materials, including 2,2,6,6tetramethylpiperidinooxyl (TEMPO), ${ }^{37-40} \mathrm{~N}$-ethylphenothiazine, $^{41,42}$ 2-phenyl-4,4,5,5-tetramethylimidazoline-1-oxyl-3oxide, ${ }^{43}$ benzophenone, ${ }^{44} \mathrm{~N}$-methylphtalimide, ${ }^{37}$ and anthraquinone (AQ). ${ }^{45-47}$ Within the compound class of AQs, 1,4diaminoanthraquinones (DAAQs) were identified by Potash et al. as exceptionally promising redox-active molecules that can have up to five electrochemically accessible oxidation states: a neutral state, two reduced states, and two oxidized states. ${ }^{47}$ This unique behavior can be attributed to the combination of a quinone functionality (reductions), two amine functions (oxidations), and an aromatic base structure that stabilizes the reduced and oxidized species via electron delocalization. ${ }^{48}$ In particular, 1,4-bis(isopropylamino)anthraquinone (Figure 1a), available commercially as the dye Disperse Blue 134 (DB134), exhibits four highly reversible one-electron redox reactions at $-1.51,-1.98,+0.25$, and $+0.74 \mathrm{~V}$ versus $\mathrm{Ag}^{+} /$ $\mathrm{Ag}$, allowing for the construction of a symmetric RFB with a theoretical cell potential of $2.72 \mathrm{~V}$. The theoretical molar energy density of DB-134 in a symmetric RFB setup is $47 \mathrm{~W} \mathrm{~h}$ $\mathrm{mol}^{-1}$ when only considering the inner redox couples, and 120 $\mathrm{W} \mathrm{h} \mathrm{mol}{ }^{-1}$ when also considering the outer redox couples. Both values exceed the theoretical molar energy density of VRB electrolytes ( $34 \mathrm{~W} \mathrm{~h} \mathrm{~mol}^{-1}$ ). Unfortunately, DB-134 is poorly soluble in organic solvents (approx. $20 \mathrm{mmol} \mathrm{L}^{-1}$ in acetonitrile and approx. $200 \mathrm{mmol} \mathrm{L}^{-1}$ in toluene), which strongly limits the energy densities that can actually be achieved. ${ }^{47}$ Therefore, designing a DAAQ derivative which

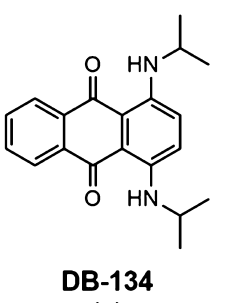

(a)

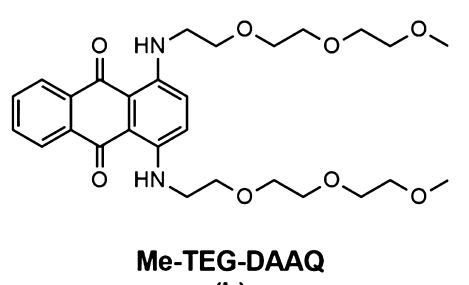

(b)
Figure 1. Chemical structures of (a) 1,4-bis(isopropylamino)anthraquinone (DB-134) and (b) 1,4-bis((2-(2-(2-methoxyethoxy)ethoxy)ethyl)amino)anthracene-9,10-dione (Me-TEG-DAAQ).

overcomes this solubility problem is of great interest to the field of RFBs.

In this paper, we report on the functionalization of the amino groups in the DAAQ structure with triethylene glycol monomethyl ether (Me-TEG) chains. The resulting compound, 1,4-bis((2-(2-(2-methoxyethoxy)ethoxy)ethyl)amino)anthracene-9,10-dione (Me-TEG-DAAQ), (Figure $1 \mathrm{~b}$ ) is miscible in any ratio with acetonitrile $(\mathrm{MeCN})$ and 1,2dimethoxyethane (DME), so high electrolyte concentrations can be achieved, and the compound also retains the reversible electrochemical properties of DAAQs. Proof-of-concept galvanostatic cycling studies in nonoptimized symmetric cells that consider only the inner redox couples are very promising, as high cell potentials can be reached with only limited capacity fading and with Coulombic efficiencies exceeding $96 \%$.

\section{EXPERIMENTAL SECTION}

Chemicals. 1,4-Dihydroxyanthraquinone (quinizarin, 96\%), methanesulfonyl chloride ( $\mathrm{MsCl}, 99.5 \%)$, 2-butanone (methyl ethyl ketone, MEK, $\geq 99 \%$, extra pure), tetraethylammonium chloride hydrate (TEACl, 99\%), DME ( $\geq 99 \%$, extra dry, over molecular sieves), acetonitrile (MeCN, 99.9\%, extra dry, over molecular sieves), and dichloromethane (DCM, 99.8\%, extra dry, over molecular sieves) were purchased from Acros Organics (Geel, Belgium). Sodium dithionite $\left(\mathrm{Na}_{2} \mathrm{~S}_{2} \mathrm{O}_{4}\right.$, purified, $\geq 86 \%$ ) and ethyl acetate (EtOac, $\geq 99.7 \%$, for HPLC) were purchased from Honeywell Riedel-deHaën (Germany). Triethylene glycol monomethyl ether (Me-TEG-OH, purum, $\geq 97 \%$ by GC) was purchased from Sigma-Aldrich (Diegem, Belgium). Ammonia $\left(\mathrm{NH}_{3}\right) 25$ wt \% aqueous solution (analytical reagent grade) was purchased from VWR (Haasrode, Belgium). Sodium hydroxide $(\mathrm{NaOH}$, analytical reagent grade) and methanol $(\mathrm{MeOH}, \geq 99.9 \%$, synthesis grade) were purchased from Fisher Scientific (Asse, Belgium). Triethylamine (TEA, $\geq 99.5 \%$, for synthesis) was purchased from Carl Roth (Karlsruhe, Germany). Potassium carbonate $\left(\mathrm{K}_{2} \mathrm{CO}_{3}\right.$, analytical reagent grade) and ammonium chloride $\left(\mathrm{NH}_{4} \mathrm{Cl}\right.$, analytical reagent grade) were purchased from Chem-Lab (Zedelgem, Belgium). Lithium bis(trifluoromethylsulfonyl)imide $\left(\mathrm{LiTf}_{2} \mathrm{~N}, 99 \%\right)$ was purchased from Iolitec (Heilbronn, Germany). Silver nitrate $\left(\mathrm{AgNO}_{3}, \geq 99 \%\right)$ was purchased from Alfa Aesar (Karlsruhe, Germany) and was dried for $12 \mathrm{~h}$ on a Schlenk line at room temperature prior to use. The synthesized products, Me-TEG-DAAQ and tetraethylammonium bis(trifluoromethylsulfonyl)imide $\left(\mathrm{TEATf}_{2} \mathrm{~N}\right)$, were dried on a Schlenk line at $70{ }^{\circ} \mathrm{C}$ for $12 \mathrm{~h}$ prior to use and were stored in an argon-filled glovebox with water and oxygen concentrations below 1 ppm. All chemicals were used as received, unless stated otherwise.

Characterization. Melting points were measured on a MettlerToledo DSC-1 differential scanning calorimeter at a heating rate of 10 ${ }^{\circ} \mathrm{C} \min ^{-1}$ under a helium atmosphere. Samples were weighed (3-12 $\mathrm{mg}$ ) inside aluminum crucibles and subsequently sealed with an aluminum cap. The samples were cycled twice (heating first) between -70 and $90{ }^{\circ} \mathrm{C}$. The melting point value determined in the second 
cycle is reported. The density of Me-TEG-DAAQ was measured on an Anton Paar DMA $4500 \mathrm{M}$ densitometer. The sample was injected into the density chamber of the device using a syringe. The temperature during the density measurements was controlled using the internal thermostat of the device. Infrared spectra were recorded on a Bruker VERTEX 70 FTIR spectrometer in the attenuated total reflectance (ATR) mode, equipped with the Bruker PLATINUM ATR module and a diamond ATR crystal. Each measurement consisted of 32 scans at a resolution of $4 \mathrm{~cm}^{-1}$. FTIR spectra were analyzed with OPUS 7.0 software. NMR spectra were recorded on either a Bruker $600 \mathrm{MHz}$ AVANCE II+ spectrometer, operating at $600 \mathrm{MHz}$ for ${ }^{1} \mathrm{H}$ NMR and $150 \mathrm{MHz}$ for ${ }^{13} \mathrm{C}$ NMR or a Bruker 400 $\mathrm{MHz}$ AVANCE III HD spectrometer, operating at $400 \mathrm{MHz}$ for ${ }^{1} \mathrm{H}$ NMR and $100 \mathrm{MHz}$ for ${ }^{13} \mathrm{C}$ NMR. Tetramethylsilane was used as internal reference $\left(0.00 \mathrm{ppm}\right.$ for ${ }^{1} \mathrm{H}$ and $\left.{ }^{13} \mathrm{C}\right)$. NMR spectra were analyzed with TopSpin 4.0.2. UV-vis spectra were recorded on a Varian Cary 6000i UV-vis-NIR spectrometer at a scan rate of $10 \mathrm{~nm}$ $\mathrm{s}^{-1}$ with $1 \mathrm{~nm}$ intervals. The instrument was used in the double-beam mode. Samples were diluted to fall within an absorbance range of $0.1-1.0$ and were measured in quartz glass cuvettes with a path length of $1 \mathrm{~cm}$. Blanks consisted of the supporting electrolyte $\left(\right.$ TEATf $_{2} \mathrm{~N}$ ) dissolved in $\mathrm{MeCN}$ or DME at the same concentration as the samples and were measured in matching cuvettes. The saturated or $1 \mathrm{~mol} \mathrm{~L}^{-1}$ samples were diluted in threefold, and the determined concentrations are given as an average of three separate measurements.

Electrochemistry. All the electrochemical measurements were performed inside an argon-filled glovebox with water and oxygen concentrations below $1 \mathrm{ppm}$. Cyclic voltammograms (CVs) were measured using an Autolab PGSTAT302N potentiostat and Nova 2.1 software. The working electrode for $\mathrm{CV}$ was a polished platinum disk electrode $(\phi=0.5 \mathrm{~mm})$, the counter electrode was a piece of platinum coated silicon wafer (approx. surface area $=0.0025 \mathrm{dm}^{-2}$ ), and the scan rate was $50 \mathrm{mV} \mathrm{s}^{-1}$, unless stated otherwise. The reference electrode consisted of a silver wire, submerged in a solution of silver nitrate $\left(0.01 \mathrm{~mol} \mathrm{~L}^{-1}\right)$ and $\operatorname{TEATf}_{2} \mathrm{~N}\left(0.1 \mathrm{~mol} \mathrm{~L}^{-1}\right)$ in anhydrous acetonitrile, contained inside a fritted glass tube. The CVs were started at open circuit potential (OCP). For the $\mathrm{CV}$ measurements, IR drop compensation was applied by measuring the impedance of the setup by electrochemical impedance spectroscopy (EIS). EIS spectra were recorded at OCP, using an Autolab PGSTAT302N potentiostat and Nova 2.1 software in a frequency range of $0.1 \mathrm{~Hz}-100 \mathrm{MHz}$ for the cycling cells. Galvanostatic cycling was performed in two-electrode mode, using an EG\&G Princeton Applied Research potentiostat and Corrware software. A custom-built sandwich cell with $4 \mathrm{~mm}$ thick circular carbon felt electrodes $(\phi=30$ $\mathrm{mm}$ ) and carbon paper current collectors was used. Nafion XL proton exchange membranes were used, which were activated with a 5 wt \% hydrogen peroxide solution at room temperature and subsequently a $1 \mathrm{~mol} \mathrm{~L}^{-1}$ sulfuric acid solution at $80{ }^{\circ} \mathrm{C}$ for $1 \mathrm{~h}$. The activated membranes were then soaked for $24 \mathrm{~h}$ in an aqueous $1 \mathrm{~mol} \mathrm{~L}^{-1}$ tetraethylammonium hydroxide solution to exchange the protons with $\mathrm{TEA}^{+}$cations, rinsed with deionized water, subsequently soaked in an anhydrous solvent (DME or MeCN) for $24 \mathrm{~h}$, and finally in $1 \mathrm{~mol} \mathrm{~L}^{-1}$ TEATf $_{2} \mathrm{~N}$ dissolved in the anhydrous solvent for $48 \mathrm{~h}$. The cycling electrolytes were prepared in volumetric flasks, and subsequently, 1.2 $\mathrm{mL}$ was pipetted out and absorbed in the carbon felt electrodes during assembly of the cell.

Synthesis Procedures. 9,10-Dihydroxy-2,3-dihydroanthracene1,4-dione (Leucoquinizarin). Quinizarin (2.99 g, 1.0 equiv, 12.447 $\mathrm{mmol}$ ) was added to a stirring solution of $\mathrm{NaOH}(1.26 \mathrm{~g}, 2.5$ equiv, $31.502 \mathrm{mmol})$ in $\mathrm{H}_{2} \mathrm{O}(400 \mathrm{~mL})$ inside a two-neck $500 \mathrm{~mL}$ roundbottom flask equipped with a reflux condenser. A dark purple solution with suspended quinizarin was formed, which was stirred at room temperature for $15 \mathrm{~min} . \mathrm{Na}_{2} \mathrm{~S}_{2} \mathrm{O}_{4}(15.50 \mathrm{~g}, 7.2$ equiv, $89.024 \mathrm{mmol})$ was added to the purple suspension, resulting in an immediate color change to an orange-brown suspension. The temperature was increased to $90{ }^{\circ} \mathrm{C}$ and the suspension was stirred for $4 \mathrm{~h}$ under nitrogen atmosphere, after which the solution turned pale yellow with a bright yellow solid floating on top. The reaction mixture was cooled to room temperature, and the solid was collected by vacuum filtration, washed with deionized water $(20 \mathrm{~mL})$, transferred to a flask, and dried for $12 \mathrm{~h}$ on a Schlenk line at room temperature. The final leucoquinizarin product was obtained as a fine bright yellow solid (2.55 g, $10.53 \mathrm{mmol}, 85 \%$ yield). ${ }^{1} \mathrm{H}$ NMR $\left(600 \mathrm{MHz}, \mathrm{CDCl}_{3}, \delta /\right.$ ppm): $13.61(\mathrm{~s}, 2 \mathrm{H}), 8.46-8.44(\mathrm{~m}, 2 \mathrm{H}), 7.79-7.77(\mathrm{~m}, 2 \mathrm{H}), 3.08$ (s, 4H). ${ }^{13} \mathrm{C}$ NMR $\left(600 \mathrm{MHz}, \mathrm{CDCl}_{3}, \delta / \mathrm{ppm}\right): 201.00,155.34$, $130.58,129.44,124.74,107.52,35.96$. IR (ATR, $\left.\nu_{\max } / \mathrm{cm}^{-1}\right): 3370(\nu$ $\mathrm{O}-\mathrm{H}), 2966(\nu \mathrm{O}-\mathrm{H}), 1634(\nu \mathrm{C}=\mathrm{O}), 1611(\nu \mathrm{C}=\mathrm{C}), 1580$, 1504, $1464(\delta \mathrm{C}-\mathrm{H}), 1422,1386(\delta \mathrm{O}-\mathrm{H}), 1312,1279,1257,1229$, 1193, 1156, 1099, 1084, 1029, 1005, 987, 946, 921, 901, 815, 771, $742,682,652$.

2-(2-(2-Methoxyethoxy)ethoxy)ethyl Methanesulfonate (MeTEG-OMs). 2-(2-(2-Methoxyethoxy)ethoxy)ethanol (triethylene glycol monomethyl ether, Me-TEG-OH) (16.43 g, 1.0 equiv, $0.100 \mathrm{~mol}$ ) and TEA (17.0 mL, 1.2 equiv, $0.122 \mathrm{~mol}$ ) were dissolved in anhydrous DCM $(60 \mathrm{~mL})$. The solution was stirred under dry nitrogen gas inside a $250 \mathrm{~mL}$ round-bottom flask equipped with a dropping funnel and placed inside an ice bath. After 5 min of cooling, a solution of methanesulfonyl chloride $(\mathrm{MsCl})(10.8 \mathrm{~mL}, 1.4$ equiv, $0.140 \mathrm{~mol})$ in anhydrous DCM $(20 \mathrm{~mL})$ was added dropwise to this solution and under vigorous stirring. The immediate formation of a white/pale yellow precipitate (triethylammonium chloride) was observed. The reaction mixture was further stirred under a nitrogen atmosphere in the ice bath overnight and was allowed to warm up to room temperature. A saturated aqueous $\mathrm{NaHCO}_{3}$ solution $(50 \mathrm{~mL})$ was added, and the mixture was stirred at room temperature for 30 $\mathrm{min}$. The layers were separated, and the organic phase was washed with $1 \mathrm{~mol} \mathrm{~L}^{-1}$ aqueous $\mathrm{HCl}$ solution $(2 \times 50 \mathrm{~mL})$. The acidic washing phases were back-extracted with $\mathrm{DCM}(2 \times 100 \mathrm{~mL})$, and the combined organic phases were dried over $\mathrm{Na}_{2} \mathrm{SO}_{4}$ and concentrated on a rotary evaporator to give 2-(2-(2-methoxyethoxy)ethoxy)ethyl methanesulfonate (Me-TEG-OMs) (22.35 g, $0.092 \mathrm{~mol}$, $92 \%$ yield) as an orange/yellow liquid. ${ }^{1} \mathrm{H}$ NMR $\left(400 \mathrm{MHz}, \mathrm{CDCl}_{3}\right.$, $\delta / \mathrm{ppm}): 4.37(\mathrm{t}, 2 \mathrm{H}), 3.76(\mathrm{t}, 2 \mathrm{H}), 3.67-3.61(\mathrm{~m}, 6 \mathrm{H}), 3.53(\mathrm{t}, 2 \mathrm{H})$, $3.37(\mathrm{~s}, 3 \mathrm{H}), 3.08(\mathrm{~s}, 3 \mathrm{H}) .{ }^{13} \mathrm{C}$ NMR $\left(400 \mathrm{MHz}, \mathrm{CDCl}_{3}, \delta / \mathrm{ppm}\right)$ : 71.84, 70.54, 70.45, 70.43, 69.47, 68.94, 58.91, 37.58. IR (ATR, $\nu_{\max }$ / $\left.\mathrm{cm}^{-1}\right): 3325,1633,1504,1467,1389(\nu \mathrm{S}=\mathrm{O}), 1326,1279,1196$, 1086 ( $\nu$ C-O), 1049, 950, 928, 680.

2-(2-(2-Methoxyethoxy)ethoxy)ethanamine (Me-TEG-NH $\mathrm{N}_{2}$. MeTEG-OMs $(15.07 \mathrm{~g}, 1$ equiv, $0.062 \mathrm{~mol})$ was added to a stirring solution of $\mathrm{NH}_{4} \mathrm{Cl}(120 \mathrm{~g})$ in 25 wt \% aqueous $\mathrm{NH}_{3}(800 \mathrm{~mL}, 83$ equiv, $5.154 \mathrm{~mol} \mathrm{NH}_{3}$ ) inside a $1000 \mathrm{~mL}$ Erlenmeyer flask, and the mixture was stirred at room temperature for two days. Subsequently, $\mathrm{NaCl}(120 \mathrm{~g})$ was added, and the mixture was stirred until complete dissolution. The reaction mixture was extracted with DCM $(8 \times 100$ $\mathrm{mL})$ and the combined organic phases were dried over $\mathrm{Na}_{2} \mathrm{SO}_{4}$ and concentrated on a rotary evaporator to give 2-(2-(2-methoxyethoxy)ethoxy)ethanamine (Me-TEG- $\left.\mathrm{NH}_{2}\right)(7.11 \mathrm{~g}, 0.044 \mathrm{~mol}, 70 \%$ yield) as a pale yellow liquid. ${ }^{1} \mathrm{H} \mathrm{NMR}\left(400 \mathrm{MHz}, \mathrm{CDCl}_{3}, \delta / \mathrm{ppm}\right)$ : $3.67-$ $3.63(\mathrm{~m}, 6 \mathrm{H}), 3.56(\mathrm{t}, J=4.7 \mathrm{~Hz}, 2 \mathrm{H}), 3.51(\mathrm{t}, J=5.2 \mathrm{~Hz}, 2 \mathrm{H}), 3.38$ $(\mathrm{s}, 3 \mathrm{H}), 2.86(\mathrm{t}, J=5.2 \mathrm{~Hz}, 2 \mathrm{H}), 1.42(\mathrm{~s}$, broad, $2 \mathrm{H}) .{ }^{13} \mathrm{C}$ NMR $(400$ $\left.\mathrm{MHz}, \mathrm{CDCl}_{3}, \delta / \mathrm{ppm}\right): 73.40,71.85,70.51,70.44,70.19,58.91,41.72$. IR (ATR, $\left.\nu_{\max } / \mathrm{cm}^{-1}\right): 3374(\nu \mathrm{N}-\mathrm{H}), 2866(\nu \mathrm{C}-\mathrm{H}), 1596,1454$, 1350, 1326, 1297, 1247, 1199, 1102 ( $\nu$ C-O), 1028, 984, 928, 849, 671.

1,4-Bis((2-(2-(2-methoxyethoxy)ethoxy)ethyl)amino)anthracene-9,10-dione (Me-TEG-DAAQ). Me-TEG-NH $\mathrm{N}_{2}$ (6.96 g, 10 equiv, $42.64 \mathrm{mmol})$ was added to leucoquinizarin $(0.99 \mathrm{~g}$, 1 equiv, $4.08 \mathrm{mmol})$ and $\mathrm{Na}_{2} \mathrm{~S}_{2} \mathrm{O}_{4}(1.00 \mathrm{~g}, 11.49 \mathrm{mmol})$ inside a $20 \mathrm{~mL}$ glass vial equipped with a magnetic stirring bar. The vial was brought under a nitrogen atmosphere, sealed tightly with a screwcap lined with a silicone septum and with Parafilm, and the mixture was stirred at 80 ${ }^{\circ} \mathrm{C}$ overnight. Subsequently, the reaction mixture was cooled to room temperature, the screwcaps were removed, and it was further stirred under open air overnight. The reaction mixture was poured into deionized water $(50 \mathrm{~mL})$ and was extracted with methyl ethyl ketone (MEK) $(150 \mathrm{~mL}+2 \times 50 \mathrm{~mL})$, and the combined organic phases were washed with a $1: 3$ mixture of $1 \mathrm{~mol} \mathrm{~L}^{-1}$ aqueous $\mathrm{HCl}$ and brine $(2 \times 50 \mathrm{~mL})$ and then with pure brine $(2 \times 50 \mathrm{~mL})$. The combined organic phases were dried over $\mathrm{MgSO}_{4}$ and concentrated on a rotary 
evaporator to give 1,4-bis((2-(2-(2-methoxyethoxy)ethoxy)ethyl)amino)anthracene-9,10-dione as a dark blue viscous liquid (1.93 g, $3.64 \mathrm{mmol}, 89 \%$ crude yield). The crude product was purified by column chromatography on silica gel with eluent EtOAc and then EtOAc/MeOH 9:1. The bright blue band $\left(R_{\mathrm{f}}=0.52\right.$ with EtOAc/ $\mathrm{MeOH} 9: 1)$ was isolated (70\% final yield). ${ }^{1} \mathrm{H}$ NMR (600 MHz, $\left.\mathrm{CD}_{3} \mathrm{CN}, \delta / \mathrm{ppm}\right): 3.28(\mathrm{~s}, 6 \mathrm{H}), 3.46-3.48(\mathrm{~m}, 4 \mathrm{H}), 3.55-3.59(\mathrm{~m}$, $8 \mathrm{H}), 3.61-3.63(\mathrm{~m}, 4 \mathrm{H}), 3.65-3.66(\mathrm{~m}, 4 \mathrm{H}) 3.75(\mathrm{t}, J=5.5 \mathrm{~Hz}$, $4 \mathrm{H}), 7.31(\mathrm{~s}, 2 \mathrm{H}), 7.71-7.74(\mathrm{~m}, 2 \mathrm{H}), 8.25-8.28(\mathrm{~m}, 2 \mathrm{H}), 10.77(\mathrm{t}, J$ $=5.0 \mathrm{~Hz}, 2 \mathrm{H}) \cdot{ }^{13} \mathrm{C} \mathrm{NMR}\left(400 \mathrm{MHz}, \mathrm{CD}_{3} \mathrm{CN}, \delta / \mathrm{ppm}\right): 181.80$, 146.07, 134.45, 131.99, 125.78, 123.91, 109.37, 71.65, 70.31, 70.17, 70.10, 69.57, 57.90, 42.40. IR (ATR, $\left.\nu_{\max } / \mathrm{cm}^{-1}\right): 3067(\nu \mathrm{N}-\mathrm{H})$, $2866(\nu \mathrm{C}-\mathrm{H}), 1643(\nu \mathrm{C}=\mathrm{O}), 1609,1593,1576,1558(\nu \mathrm{C}-\mathrm{C})$, $1520,1452(\delta \mathrm{C}-\mathrm{H}), 1416,1378,1390,1352,1281,1256(\nu \mathrm{C}-\mathrm{N})$, 1199, 1171, 1103, 1051, 1021, 922, 849, 819, 800, 730, 662, 564, 497, 463. $\mathrm{CHN}$ found (calculated) for $\mathrm{C}_{28} \mathrm{H}_{38} \mathrm{~N}_{2} \mathrm{O}_{8}$ : C, 63.85 (63.38) \%; H, 7.28 (7.22) \%; N, 5.07 (5.28) \%. UV-vis ( $\left.\mathrm{MeCN}, \lambda_{\max } / \mathrm{nm}\right): 591$, 636. mp $25{ }^{\circ} \mathrm{C}$. Density $\left(25^{\circ} \mathrm{C}\right): 1.20 \mathrm{~kg} \mathrm{dm}^{-3}$.

\section{RESULTS AND DISCUSSION}

Synthesis and Physicochemical Properties. In the RFB literature, several cases have been reported where the solubility of a redox-active species was successfully increased by introducing oligoethylene glycol ether functionalities in their structure. $^{40,45}$ This strategy was employed in order to synthesize a highly soluble DAAQ derivative, by introducing tri(ethylene glycol) monomethyl ether (Me-TEG) chains on the 1- and 4-positioned amino groups of the DAAQ structure (Figure 2). Synthesis of 1,4-DAAQs is generally straightfor-

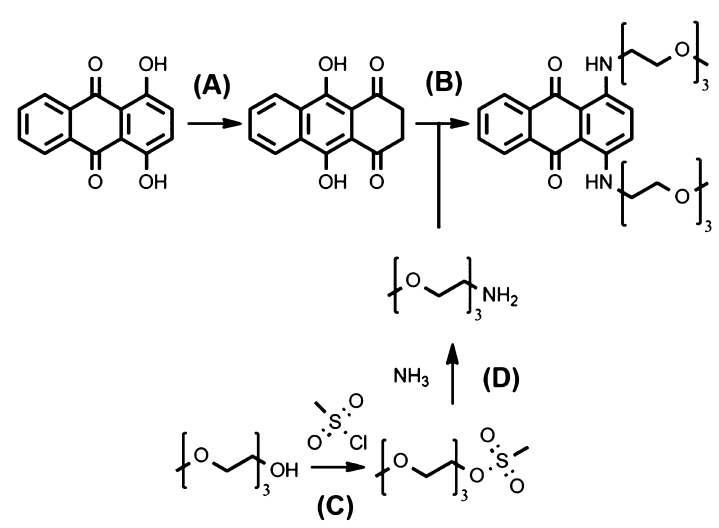

Figure 2. Procedure for the synthesis of Me-TEG-DAAQ. Reaction conditions: (A) $\mathrm{Na}_{2} \mathrm{~S}_{2} \mathrm{O}_{4}, \mathrm{NaOH}, \mathrm{H}_{2} \mathrm{O}, \mathrm{N}_{2}, 90{ }^{\circ} \mathrm{C}, 4$ h. (B) 1 . $\mathrm{Na}_{2} \mathrm{~S}_{2} \mathrm{O}_{4}, \mathrm{~N}_{2}, 80^{\circ} \mathrm{C}, 16$ h; 2. $\mathrm{O}_{2}$, RT, 16 h. (C) 1. DCM, TEA, $\mathrm{N}_{2}, 0$ ${ }^{\circ} \mathrm{C}, 30$ min; 2. $\mathrm{N}_{2}$, RT, 16 h. (D) $\mathrm{NH}_{4} \mathrm{Cl}, \mathrm{H}_{2} \mathrm{O}, \mathrm{RT}, 48 \mathrm{~h}$.

ward via a substitution reaction of the hydroxyl groups of 1,4dihydroxyanthraquinone (quinizarin), ${ }^{49}$ or its reduced form leucoquinizarin, ${ }^{50}$ with the corresponding primary amines. The required amine starting product, 2-(2-(2-methoxyethoxy)ethoxy)ethanamine (Me-TEG- $\mathrm{NH}_{2}$ ), was not commercially available and was synthesized in high yield $(70 \%)$ via a twostep procedure from commercially available 2-(2-(2methoxyethoxy)ethoxy)ethanol (triethylene glycol monomethyl ether, Me-TEG-OH) (Figure 2). In accordance with a literature procedure, the alcohol was first converted to the methanesulfonate derivative (Me-TEG-OMs) by the reaction with methanesulfonyl chloride $(\mathrm{MsCl})$, and subsequently to Me-TEG- $\mathrm{NH}_{2}$ by the reaction with an excess of ammonia solution. ${ }^{51}$ The reaction of leucoquinizarin with Me-TEG-NH was performed in solventless conditions to give the desired product, Me-TEG-DAAQ in good yield (70\% after purifica- tion). This method was found to be superior to the procedure reported by Gianoncelli et al. where the reaction is performed in basic aqueous medium and the product was only isolated in poor yield ( $30 \%$ after purification), starting from the same amount of reagents. ${ }^{50}$ The detailed synthetic procedures and characterization data $\left({ }^{1} \mathrm{H}\right.$ and ${ }^{13} \mathrm{C}$ NMR, FTIR, and CHN analysis) of Me-TEG-DAAQ and all precursors can be found in the Experimental Section. The integrated ${ }^{1} \mathrm{H}$ and ${ }^{13} \mathrm{C}$ NMR spectra of Me-TEG-DAAQ with peak assignment can be found in the Supporting Information (Figures S1 and S2).

Me-TEG-DAAQ is a dark blue compound with a melting point of $25{ }^{\circ} \mathrm{C}$, as determined by differential scanning calorimetry. This low melting point is most likely a consequence of the side chains with a high degree of conformational freedom, increasing the entropy of melting. Attaching oligo(ethylene oxide) chains to aromatic molecules is a strategy that has been also used to lower the melting points of liquid crystals with extended aromatic cores. ${ }^{52,53}$ The increased conformational freedom can in turn be advantageous to achieve high solubility because the entropy of dissolution is hereby greatly increased. The density of Me-TEG-DAAQ in the liquid state was measured at several temperatures ranging from 25 to $80{ }^{\circ} \mathrm{C}$, and from this, its molar concentration limit was calculated (Figure S3). Like most liquids, the density of Me-TEG-DAAQ decreases linearly with temperature, from $1.20 \mathrm{~kg} \mathrm{dm}^{-3}$ at $25{ }^{\circ} \mathrm{C}$ to $1.16 \mathrm{~kg} \mathrm{dm}^{-3}$ at $80^{\circ} \mathrm{C}$. The calculated molar concentration decreases from $2.27 \mathrm{~mol} \mathrm{~L}^{-1}$ at $25{ }^{\circ} \mathrm{C}$ to $2.19 \mathrm{~mol} \mathrm{~L}^{-1}$ at $80{ }^{\circ} \mathrm{C}$. A molar concentration of almost $2.3 \mathrm{~mol} \mathrm{~L}^{-1}$ at $25^{\circ} \mathrm{C}$ shows the potential of Me-TEGDAAQ to prepare highly concentrated electrolytes for RFBs.

Solubility Studies by UV-Vis Spectroscopy. Me-TEGDAAQ is liquid close to room temperature, but because it is a neutral molecule, it cannot be used as a RFB electrolyte in the pure state. An inert organic salt has to be added as a supporting electrolyte to insure conductivity, and an organic solvent has to be added as well in order to lower the viscosity of the electrolyte. A polar organic solvent is preferred over an apolar solvent so that the supporting electrolyte has high solubility. Therefore, it is also important that the redox-active species has high polarity so it can be dissolved in high concentrations as well. The diaminoanthraquinone structure on its own is rather apolar because it does not have many polar groups in relation to its apolar aromatic core. This explains the low solubility of DB-134 in acetonitrile $\left(\sim 20 \mathrm{mmol} \mathrm{L}^{-1}\right)$ and the increased solubility in toluene $\left(\sim 200 \mathrm{mmol} \mathrm{L}^{-1}\right) \cdot{ }^{47}$ On the other hand, Me-TEG-DAAQ is significantly more polar because of the oxygen atoms in the triethylene glycol monomethyl ether groups. The increased polarity of Me-TEG-DAAQ over DB134 was demonstrated in a simple thin-layer chromatography experiment (Figure S4). Because of its high polarity, as well as its high entropy of dissolution, Me-TEG-DAAQ is miscible in any ratio with both $\mathrm{MeCN}$ and DME. DAAQ molecules strongly absorb in the visible region of the electromagnetic spectrum, which results in their intense colors. Therefore, UV-vis absorption spectroscopy was used to demonstrate the high solubility of Me-TEG-DAAQ in MeCN and DME, compared to DB-134. The influence of $\operatorname{TEATf}_{2} \mathrm{~N}$ on the solubility was also studied. The visible spectra of DB-134 and Me-TEG-DAAQ dissolved in $\mathrm{MeCN}$ and DME were recorded in the 800-400 $\mathrm{nm}$ spectral range (Figure S5). When dissolved in DME, DB-134 has two absorption maxima at 593 and $640 \mathrm{~nm}$, of which the latter is the most intense. Around approx. $550 \mathrm{~nm}$, a less intense absorption band is 
observed. When dissolved in $\mathrm{MeCN}$, the absorption maxima are shifted to slightly lower wavelengths, that is, 591 and 637 $\mathrm{nm}$. The visible spectrum of Me-TEG-DAAQ is very similar to that of DB-134, indicating that the Me-TEG chains on the 1and 4-amino groups do not interfere significantly with the spectroscopic properties of DAAQs. In DME solution, the absorption maxima are located at 592 and $638 \mathrm{~nm}$ and at 591 and $636 \mathrm{~nm}$ in $\mathrm{MeCN}$ solution. The addition of $\mathrm{TEATf}_{2} \mathrm{~N}$ did not have a significant influence on the visible spectra of both DAAQs at the concentrations used in these measurements (Figure S6). For the concentration determinations, the absorption maxima of several standard solutions, typically between 10 and $70 \mu \mathrm{mol} \mathrm{L}^{-1}$, were measured to construct calibration curves. In order to determine the solubility of DB134 , saturated samples in $\mathrm{DME}$ and $\mathrm{MeCN}$, both with and without $1 \mathrm{~mol} \mathrm{~L}^{-1} \mathrm{TEATf}_{2} \mathrm{~N}$, were precisely diluted so that the absorbance values of the absorption maxima fell within the range of the calibration curves (Table 1 ). In the case of Me-

Table 1. Maximum Solubility of DB-134 in Different Solvent Systems Measured by UV-vis Absorbance Spectroscopy

\begin{tabular}{|c|c|c|c|}
\hline DAAQ & solvent system & $\begin{array}{l}\text { molar absorption } \\
\text { coefficient } \\
\varepsilon\left(\mathrm{L} \mathrm{mol}^{-1} \mathrm{~cm}^{-1}\right)\end{array}$ & $\begin{array}{l}\text { maximum } \\
\text { solubility } \\
\left(\mathrm{mol} \mathrm{L}^{-1}\right)\end{array}$ \\
\hline DB-134 & $\mathrm{MeCN}$ & $17750 \pm 30(637 \mathrm{~nm})$ & $0.0194 \pm 0.0002$ \\
\hline DB-134 & $\begin{array}{l}1 \operatorname{mol~L}^{-1} \\
\operatorname{TEATf}_{2} \mathrm{~N} \text { in } \\
\operatorname{MeCN}\end{array}$ & $17750 \pm 30(637 \mathrm{~nm})$ & $0.0157 \pm 0.0005$ \\
\hline DB-134 & DME & $17540 \pm 20(640 \mathrm{~nm})$ & $0.122 \pm 0.001$ \\
\hline DB-134 & $\begin{array}{l}1 \mathrm{~mol} \mathrm{~L}^{-1} \\
\operatorname{TEATf}_{2} \mathrm{~N} \text { in } \\
\text { DME }\end{array}$ & $17530 \pm 30(640 \mathrm{~nm})$ & $0.091 \pm 0.002$ \\
\hline
\end{tabular}

TEG-DAAQ solutions with a theoretical concentration of 1 mol L $\mathrm{L}^{-1}$ were prepared and diluted in a similar way (Table 2 ). The calibration curves of the different systems can be found in the Supporting Information (Figures S7 and S8).

Table 2. Experimentally Measured Concentrations of $1 \mathrm{~mol}$ $\mathrm{L}^{-1}$ Me-TEG-DAAQ in Different Solvent Systems Measured by UV-Vis Absorbance Spectroscopy

\begin{tabular}{|c|c|c|c|}
\hline DAAQ & $\begin{array}{l}\text { solvent } \\
\text { system }\end{array}$ & $\begin{array}{l}\text { molar absorption } \\
\text { coefficient } \\
\varepsilon\left(\mathrm{L} \mathrm{mol}^{-1} \mathrm{~cm}^{-1}\right)\end{array}$ & $\begin{array}{c}\text { measured } \\
\text { concentration } \\
\left(\mathrm{mol} \mathrm{L}^{-1}\right)\end{array}$ \\
\hline Me-TEG-DAAQ & $\mathrm{MeCN}$ & $\begin{array}{c}15840 \pm 20 \\
(636 \mathrm{~nm})\end{array}$ & $1.036 \pm 0.004$ \\
\hline Me-TEG-DAAQ & $\begin{array}{l}1 \operatorname{mol~L}^{-1} \\
\operatorname{TEATf}_{2} \mathrm{~N} \text { in } \\
\operatorname{MeCN}\end{array}$ & $\begin{array}{c}15800 \pm 20 \\
(636 \mathrm{~nm})\end{array}$ & $1.020 \pm 0.007$ \\
\hline Me-TEG-DAAQ & DME & $\begin{array}{c}16400 \pm 10 \\
(638 \mathrm{~nm})\end{array}$ & $0.98 \pm 0.01$ \\
\hline Me-TEG-DAAQ & $\begin{array}{l}1 \mathrm{~mol} \mathrm{~L}^{-1} \\
\text { TEATf }_{2} \mathrm{~N} \text { in } \\
\text { DME }\end{array}$ & $\begin{array}{c}15500 \pm 20 \\
(638 \mathrm{~nm})\end{array}$ & $1.00 \pm 0.01$ \\
\hline
\end{tabular}

The solubility of $\mathrm{DB}-134$ in pure $\mathrm{MeCN}$, as determined by UV-vis spectroscopy, is $19 \mathrm{mmol} \mathrm{L}^{-1}$, which is in good agreement with the $20 \mathrm{mmol} \mathrm{L}^{-1}$ value mentioned by Potash et al. ${ }^{47}$ In DME, the solubility is over five times higher than in $\mathrm{MeCN}$ but still too low to be of practical use. When $1 \mathrm{~mol} \mathrm{~L}^{-1}$ TEATf $_{2} \mathrm{~N}$ is present, as it would be in a practical electrolyte, the solubility of DB-134 decreases by approx. $19 \%$ in $\mathrm{MeCN}$ and $25 \%$ in DME because of the increased polarity associated with the high salt concentration. The concentrations of solutions of Me-TEG-DAAQ in $\mathrm{MeCN}$ and DME are reasonably close to the theoretical $1 \mathrm{~mol} \mathrm{~L}^{-1}$ concentration, taking into account the random errors associated with the measurement method. Furthermore, for the $1 \mathrm{~mol} \mathrm{~L}^{-1}$ $\mathrm{TEATf}_{2} \mathrm{~N}$ samples, the concentrations are not reduced, as opposed to the DB-134 samples. Thus, it is possible to prepare electrolytes with $>1 \mathrm{~mol} \mathrm{~L}^{-1}$ Me-TEG-DAAQ even when high concentrations of the supporting electrolyte are present, which is very promising for RFB applications.

Cyclic Voltammetry. The viability of Me-TEG-DAAQ as an active species in a symmetric RFB electrolyte depends on the electrochemical accessibility and reversibility of its different oxidation states. Therefore, the electrochemical behavior of Me-TEG-DAAQ was characterized by cyclic voltammetry and compared to DB-134 as a model compound (Figure 3).
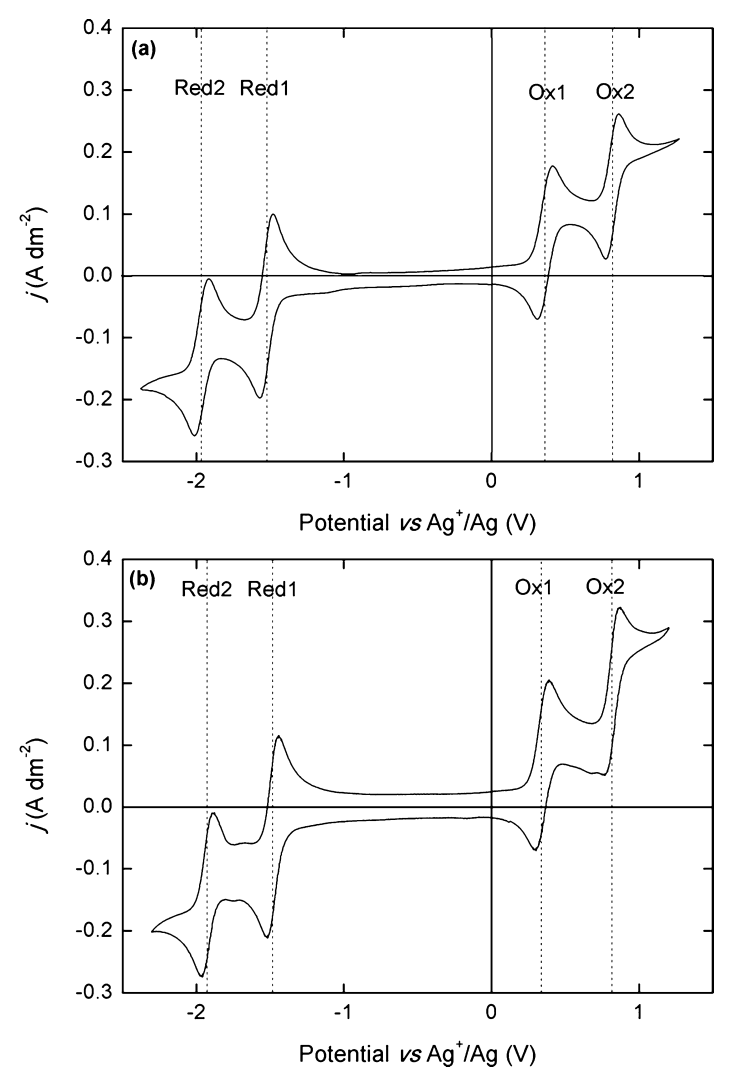

Figure 3. Cyclic voltammograms of $0.01 \mathrm{~mol} \mathrm{~L}^{-1} \mathrm{DB}-134$ (a) and $0.01 \mathrm{~mol} \mathrm{~L}^{-1} \mathrm{Me}-\mathrm{TEG}$-DAAQ (b) in $0.1 \mathrm{~mol} \mathrm{~L}^{-1} \mathrm{TEATf}_{2} \mathrm{~N}$ in DME, recorded on a platinum disc working electrode $(\phi=0.5 \mathrm{~mm})$ with a scan rate of $50 \mathrm{mV} \mathrm{s}^{-1}$. The reference electrode was a silver wire suspended in $0.01 \mathrm{~mol} \mathrm{~L}^{-1} \mathrm{AgNO}_{3}$ in $\mathrm{MeCN}$. The counter electrode was a piece of platinum-coated silicon wafer with a surface area of approx. $25 \mathrm{~mm}^{2}$. The dashed lines serve as a visual aid to indicate the formal redox potentials of the couples.

TEATf $_{2} \mathrm{~N}$ was used as the supporting electrolyte, as it provided a high conductivity through the membranes used in the cycling experiments (vide infra) and has a high solubility in $\mathrm{MeCN}$ and DME.

The CV of DB-134 displays the four expected electrochemically accessible and highly reversible redox reactions. Red 1 and Red 2 correspond to the subsequent reductions of the quinone functionality to a radical semiquinone anion and a divalent anion, respectively (Figure S9). ${ }^{48} \mathrm{Ox} 1$ and $\mathrm{Ox} 2$ correspond to the subsequent oxidations of the amino functionalities to a 
radical cation and a divalent diimine cation, respectively (Figure S10). In this particular system $\left(0.1 \mathrm{~mol} \mathrm{~L}^{-1} \mathrm{TEATf}_{2} \mathrm{~N}\right.$ in DME electrolyte, scan rate of $50 \mathrm{mV} \mathrm{s}^{-1}$ and $\left.\mathrm{Ag}^{+} / \mathrm{Ag} \mathrm{RE}\right)$, the formal redox potentials ( $E_{\text {avg }}^{0}$ given as the average of the anodic and cathodic peak potentials) of the couples are located at $-1.53 \mathrm{~V}(\operatorname{Red} 1),-1.96 \mathrm{~V}(\operatorname{Red} 2),+0.37 \mathrm{~V}(\mathrm{Ox} 1)$, and $+0.82 \mathrm{~V}(\mathrm{Ox} 2)$ versus $\mathrm{Ag}^{+} / \mathrm{Ag}$. In $0.1 \mathrm{~mol} \mathrm{~L}^{-1} \mathrm{TEATf}_{2} \mathrm{~N}$ in $\mathrm{MeCN}$, the formal redox potentials are shifted to slightly more positive values, except $\mathrm{Ox} 1$, which is located at a slightly less positive potential: $-1.46,-1.95,+0.31$, and $+0.85 \mathrm{~V}$ versus $\mathrm{Ag}^{+} / \mathrm{Ag}$ (Figure S11). The overall cyclic voltammogram of MeTEG-DAAQ in $0.1 \mathrm{~mol} \mathrm{~L}^{-1} \mathrm{TEATf}_{2} \mathrm{~N}$ in DME is similar to the CV of DB-134, with four electrochemically accessible and reversible redox transitions at $-1.48 \mathrm{~V}(\operatorname{Red} 1),-1.92 \mathrm{~V}$ $(\mathrm{Red} 2),+0.35 \mathrm{~V}(\mathrm{Ox} 1)$, and $+0.82 \mathrm{~V}(\mathrm{Ox} 2)$ versus $\mathrm{Ag}^{+} / \mathrm{Ag}$. Nevertheless, some non-negligible differences can also be observed. First, between Red 1 and Red2, a small feature is observed, which is not present in the CV of DB-134. This might be caused by a minor side reaction of the singly reduced intermediate species. Second, although the two reductions and first oxidation of Me-TEG-DAAQ look highly reversible, similar to DB-134, the second oxidation (Ox2) is visibly less reversible. This might indicate that the doubly oxidized state of Me-TEG-DAAQ is more prone to side reactions with other electrolyte components or to internal decomposition reactions. A similar result was obtained for the $\mathrm{CV}$ recorded in $0.1 \mathrm{~mol}$ $\mathrm{L}^{-1} \mathrm{TEATf}_{2} \mathrm{~N}$ in MeCN (Figure S11). The electrochemical reversibility of the four redox couples was further studied by varying the scan rate (Figure 4).

On the cathodic side, the separation potentials $\left(\Delta E_{\mathrm{p}}\right)$ between the cathodic $\left(E_{\mathrm{p}, \mathrm{c}}\right)$ and anodic $\left(E_{\mathrm{p}, \mathrm{a}}\right)$ peak potentials remain constant around $90 \mathrm{mV}$ for both Red1 and Red2, upon increasing the scan rate from 25 to $150 \mathrm{mV} \mathrm{s}^{-1}$. On the anodic side, $\Delta E_{\mathrm{p}}$ remains constant at $109 \mathrm{mV}$ for Ox1, slightly decreasing to $98 \mathrm{mV}$ at $150 \mathrm{mV} \mathrm{s}^{-1}$ and decreases from 130 to $102 \mathrm{mV}$ for Ox2. For a perfectly reversible couple, $E_{\mathrm{p}, \mathrm{c}}$ and $E_{\mathrm{p}, \mathrm{a}}$ are independent of the scan rate. Thus, Red1, Red2, and Ox1 can be regarded as highly reversible couples in this electrolyte. For $\mathrm{Ox} 2$, the decrease of $\Delta E_{\mathrm{p}}$ is caused by the shift of $E_{\mathrm{p}, \mathrm{c}}$ toward higher potentials with increasing scan rate. This behavior supports the hypothesis that the doubly oxidized species is unstable, and the increase in scan rate results in less time for side reactions or decomposition to occur. Furthermore, as the scan rate is increased, a new feature is observed in the backward scans between Ox2 and Ox1. This might also indicate the formation of an unstable intermediate by a side reaction of the doubly oxidized species. The rate constants of electron transfer were estimated by the Nicholson method and were in the $10^{-3} \mathrm{~cm} \mathrm{~s}^{-1}$ order of magnitude for both Red1 and Ox1, suggesting fast electron transfer kinetics. The complete calculations and results and discussion can be found in the Supporting Information (Tables S1 and S2). In $0.1 \mathrm{~mol} \mathrm{~L}^{-1} \mathrm{TEATf}_{2} \mathrm{~N}$ in $\mathrm{MeCN}, \Delta E_{\mathrm{p}}$ remains constant for Red 1 and Ox1 upon increasing the scan rate (Figure S12). For Ox2, a decrease of $\Delta E_{\mathrm{p}}$ with the scan rate is observed analogously to the DME electrolyte. However for Red2, $\Delta E_{\mathrm{p}}$ increases with the scan rate; thus, in $\mathrm{MeCN}$, this couple has to be regarded as quasi-reversible. For DB-134, CVs at various scan rates were recorded as well, both in DME (Figure S13) and MeCN (Figure S14).

Galvanostatic Cycling. Based on the solubility and cyclic voltammetry studies, Me-TEG-DAAQ is a very promising candidate as an active species for high energy density
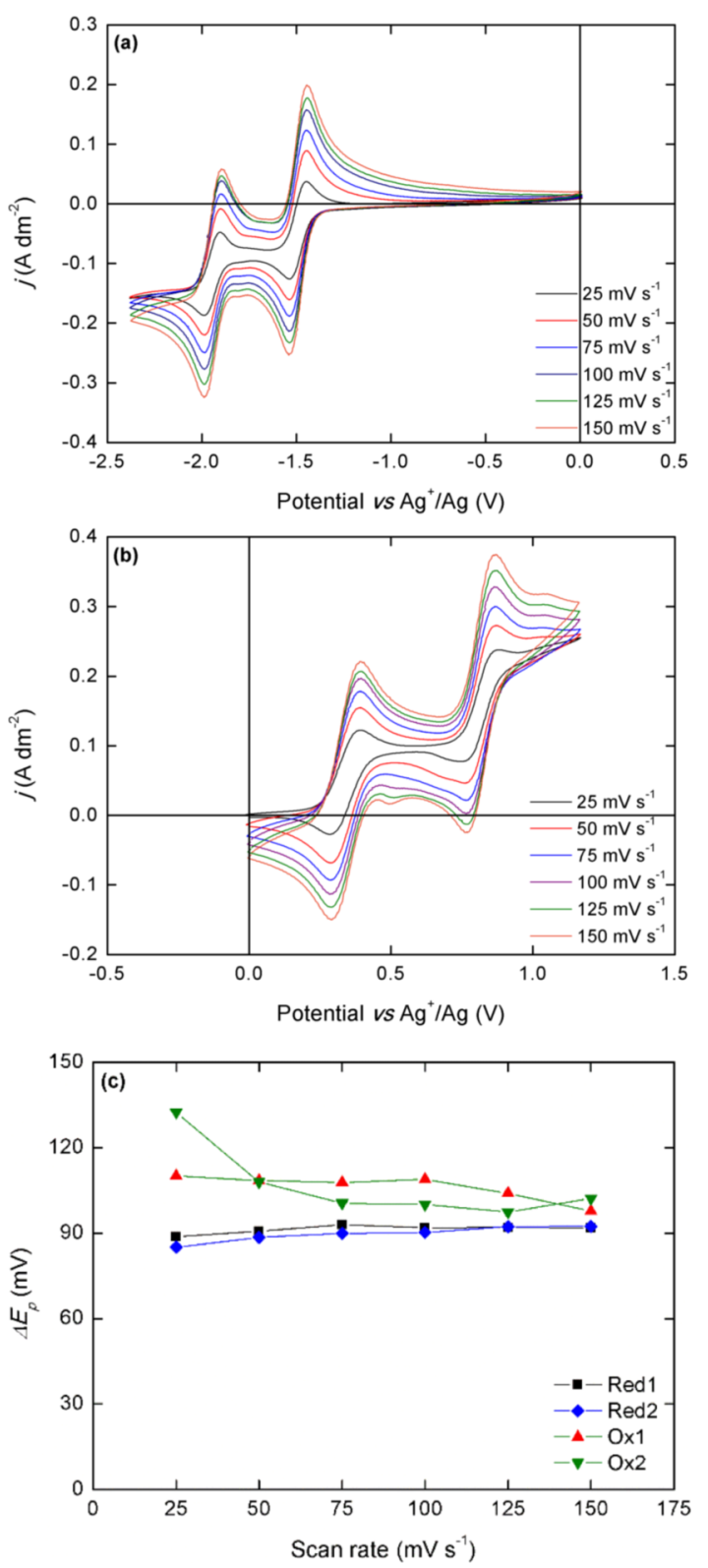

Figure 4. Cyclic voltammograms of $0.01 \mathrm{~mol} \mathrm{~L}^{-1} \mathrm{Me}-\mathrm{TEG}-\mathrm{DAAQ}$ in $0.1 \mathrm{~mol} \mathrm{~L}^{-1} \mathrm{TEATf}_{2} \mathrm{~N}$ in DME, recorded on a platinum disc working electrode $(\phi=0.5 \mathrm{~mm})$ in the range -2.4 to $+0.01 \mathrm{~V} \mathrm{vs}^{+} / \mathrm{Ag}(\mathrm{a})$ and -0.01 to $+1.2 \mathrm{~V}_{\text {vs }} \mathrm{Ag}^{+} / \mathrm{Ag}(\mathrm{b})$. The scan rate was varied from 25 to $150 \mathrm{mV} \mathrm{s}^{-1}$. The reference electrode was a silver wire suspended in $0.01 \mathrm{~mol} \mathrm{~L}^{-1} \mathrm{AgNO}_{3}$ in $\mathrm{MeCN}$. The counter electrode was a piece of platinum-coated silicon wafer with a surface area of approx. $25 \mathrm{~mm}^{2}$. (c) Plot of the separation potentials of the redox couples vs the scan rate.

symmetric RFBs. Concentrations of $>1 \mathrm{~mol} \mathrm{~L}^{-1}$ can be achieved, even when high concentrations of the supporting electrolyte are present. Furthermore, the reversible electrochemical properties of DAAQs are relatively well retained, compared to the model compound DB-134. Based on the CV of Me-TEG-DAAQ in DME (Figure 3b), the theoretical cell potential $\left(\Delta E_{\mathrm{avg}}^{0}\right)$ of a symmetric cell based on this molecule is $1.83 \mathrm{~V}$ when only considering the two inner redox couples, and $2.74 \mathrm{~V}$ when also considering the two outer redox couples. The theoretical molar energy density $\left[\varepsilon_{\text {molar }}\left(\mathrm{W} \mathrm{h} \mathrm{mol}^{-1}\right)\right]$ can be calculated according to eq 1 . 


$$
\varepsilon_{\text {molar }}=\Delta E_{\mathrm{avg}}^{0}\left(\frac{n F}{3600}\right)
$$

In this formula, $n$ is the number of exchanged electrons and $F$ is the Faraday constant. Thus, the theoretical molar energy density of Me-TEG-DAAQ in a symmetric RFB is $49 \mathrm{~W} \mathrm{~h}$ $\mathrm{mol}^{-1}$ when only considering the two inner redox couples and $122 \mathrm{~W} \mathrm{~h} \mathrm{~mol}{ }^{-1}$ when considering both sets of redox couples. In this section, proof-of-concept galvanostatic cycling experiments of dilute Me-TEG-DAAQ solutions in a static symmetric electrochemical cell are presented. A Nafion XL cation-exchange membrane was used to separate the two half cells. MeCN is often used as a solvent for nonaqueous RFB electrolytes because of its aprotic nature, wide electrochemical window, and its ability to dissolve large amounts of supporting electrolyte salts to form highly conductive solutions. However, as both the reductions and oxidations of DAAQs involve radical intermediate species, the chemical stability of the solvent against radicals also has to be taken into account. ${ }^{48}$ In this regard, DME has been shown to have an advantage over $\mathrm{MeCN}$ in recent reports, as it resulted in significantly better capacity retention for a variety of nonaqueous RFB electolytes. ${ }^{54,55}$ Therefore, the cycling experiments of MeTEG-DAAQ were conducted comparatively, using $1 \mathrm{~mol} \mathrm{~L}^{-1}$ $\mathrm{TEATf}_{2} \mathrm{~N}$ in MeCN and DME supporting electrolytes (Figure 5).

The galvanostatic cycling tests were conducted with positive and negative charging currents in order to explore Me-TEGDAAQ as both an anolyte and catholyte, respectively. In both cases, two distinct plateaus are observed in the charge curves, corresponding to the two consecutive anodic and cathodic redox couples. This shows that the maximum capacity can be reached when the electrolyte is used as an anolyte or as a catholyte, as would be required in a symmetric RFB. For the $\mathrm{MeCN}$ electrolytes, the first plateau occurs at an average potential of approx. +1.75 or $-1.75 \mathrm{~V}$, which matches the expected $1.75 \mathrm{~V}$ potential window between Red 1 and $\mathrm{Ox} 1$ in the cyclic voltammetry studies (Figure S11b). The second plateau occurs at an average potential of approx. +2.60 or $-2.60 \mathrm{~V}$, which matches the $2.70 \mathrm{~V}$ potential window between Red 2 and Ox2. For the DME electrolytes, the first and second plateaus occur at an average potential of approx. +2.10 or -2.10 and +2.90 or $-2.90 \mathrm{~V}$, which is at significantly higher potentials than the 1.83 and $2.74 \mathrm{~V}$ potential windows in the $\mathrm{CV}$ of the DME electrolyte and the plateaus of the $\mathrm{MeCN}$ electrolyte. However, this average potential difference of $0.3 \mathrm{~V}$ between the plateaus measured for the DME and $\mathrm{MeCN}$ electrolytes can be attributed to the higher impedance of the cell with the DME electrolyte, as demonstrated by EIS experiments (Figure $5 b$ ). This increased impedance induces a higher IR drop over the membrane. The location of these plateaus relative to the capacity is important to determine the appropriate cut-off potentials for the capacity retention studies (vide infra). For the $\mathrm{MeCN}$ electrolytes, cut-off potentials of +2.2 and $-2.0 \mathrm{~V}$ were used for the cycling experiments in the anolyte mode and catholyte mode, respectively. For the DME electrolytes, the cut-off potentials were +2.5 and $-2.8 \mathrm{~V}$ (Figure 6). The lower cut-off potential was $0.0 \mathrm{~V}$ for all experiments.

The theoretical capacity when only considering the first set of one-electron transitions is equal to $2.68 \mathrm{~A} \mathrm{~h} \mathrm{~L}^{-1}$ and is denoted using the black dotted line. It is clear that, within the applied cut-off potential ranges, complete capacity can be
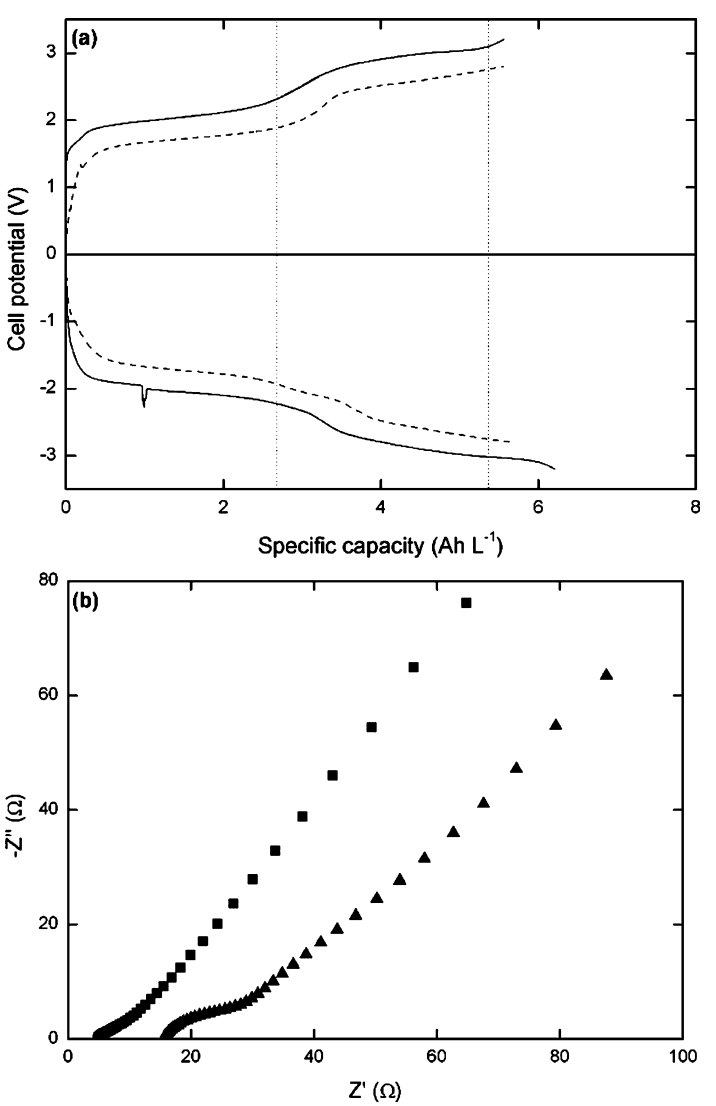

Figure 5. (a) First charge of electrolytes $(1.2 \mathrm{~mL})$ consisting of 0.1 mol L ${ }^{-1}$ Me-TEG-DAAQ and $1 \mathrm{~mol} \mathrm{~L}^{-1} \operatorname{TEATf}_{2} \mathrm{~N}$ in DME (full lines) and $\mathrm{MeCN}$ (dashed lines) in a static two-electrode symmetric cell. The current density was +0.21 or $-0.21 \mathrm{~A} \mathrm{dm}^{-2}$, for the electrolyte being used as the anolyte and catholyte, respectively. The vertical dotted lines depict the theoretical capacities for one set and both sets of redox couples. (b) Nyquist plot, recorded in the frequency range $0.1 \mathrm{~Hz}-100 \mathrm{MHz}$ on a static symmetric cell containing the abovementioned DME (triangles) and $\mathrm{MeCN}$ (squares) electrolytes.

reached in the early cycles for both DME- and MeCN-based electrolytes, when used as the anolyte as well as the catholyte. However, upon continued cycling, the cells containing the $\mathrm{MeCN}$-based electrolytes experience severe fading of the charge and discharge capacity. After 100 cycles, the residual capacities are decreased to $56 \%$ of the theoretical value for the cell in the catholyte mode and $39 \%$ for the cell in the anolyte mode. In contrast, more stable cycling performance is observed for the DME-based electrolytes, as the charge and discharge capacities remain slightly higher than theoretical for the majority of the 100 cycles, and only limited fading is observed to $93 \%$ of the theoretical value for the cell in the catholyte mode and $82 \%$ for the cell in the anolyte mode. The higher stability of the DME electrolytes is also reflected in the coulombic efficiencies of the successive cycles. For both the $\mathrm{MeCN}$ - and DME-based electrolytes, high Coulombic efficiencies are reached, showing the high efficiency of the cation exchange membranes in preventing electrolyte crossover (Table 3). However, for the DME electrolytes, the Coulombic efficiencies are consistently higher than those for the $\mathrm{MeCN}$ electrolytes, which supports the statement of Armstrong et al., that is, that $\mathrm{MeCN}$ is more prone to react with the reduced and oxidized radical species because of the 

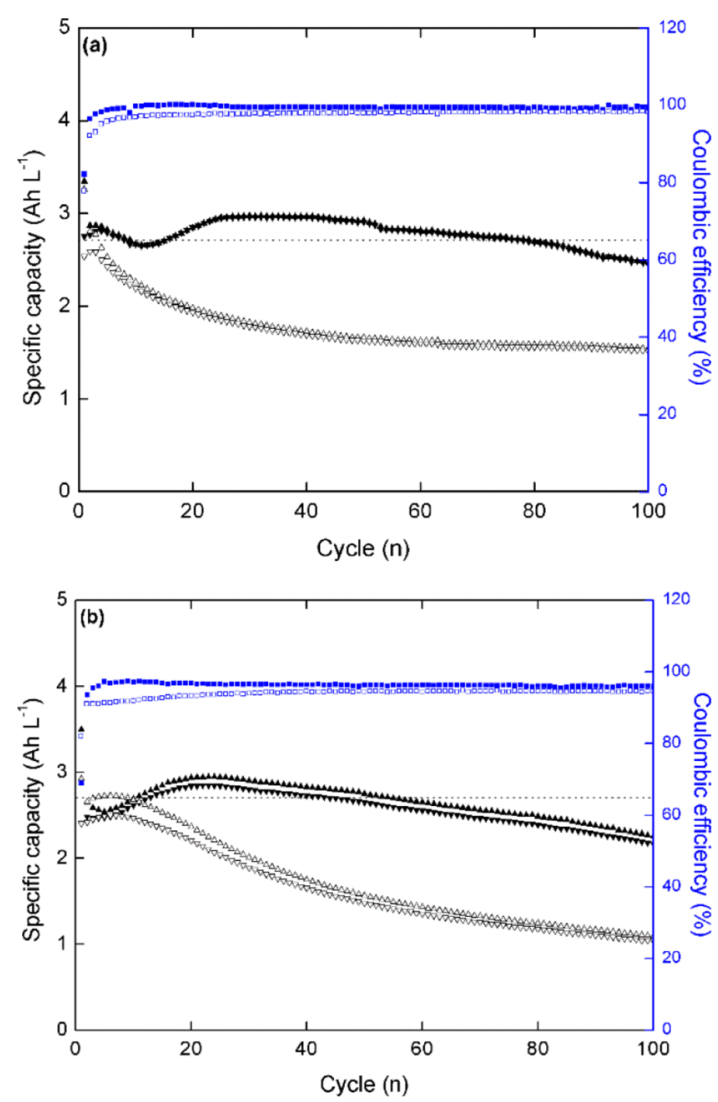

Figure 6. Charge capacities (upward triangles), discharge capacities (downward triangles), and Coulombic efficiencies (squares) over 100 cycles of $0.1 \mathrm{~mol} \mathrm{~L}^{-1} \mathrm{Me}$-TEG-DAAQ and $1 \mathrm{~mol} \mathrm{~L}^{-1} \mathrm{TEATf}_{2} \mathrm{~N}$ in DME (full symbols) and MeCN (hollow symbols), used as the catholyte (a) or anolyte (b). The dotted line denotes the theoretical capacity for one-electron transition $\left(2.68 \mathrm{~A} \mathrm{~h} \mathrm{~L}^{-1}\right)$. The current density was +0.21 or $-0.21 \mathrm{~A} \mathrm{dm}^{-2}$.

Table 3. Galvanostatic Cycling Performance at Different Cut-Off Potentials of Static Symmetric Cells Containing 0.1 mol L ${ }^{-1}$ Me-TEG-DAAQ and $1 \mathrm{~mol} \mathrm{~L}^{-1}$ TEATf $_{2} \mathrm{~N}$ in DME or $\mathrm{MeCN}^{a}$

\begin{tabular}{lcccc}
$\begin{array}{c}\text { electrolyte } \\
\text { solvent }\end{array}$ & $\begin{array}{c}\text { cut-off } \\
\text { potential } \\
(\mathrm{V})\end{array}$ & $\begin{array}{c}\text { charge } \\
\text { capacity } \\
\left(\mathrm{A} \mathrm{h} \mathrm{L}^{-1}\right)^{b}\end{array}$ & $\begin{array}{c}\text { discharge } \\
\text { capacity }_{\left(\mathrm{A} \mathrm{h} \mathrm{L}^{-1}\right)^{b}}\end{array}$ & $\begin{array}{c}\text { Coulombic } \\
\text { efficiency } \\
(\%)^{b}\end{array}$ \\
\hline $\mathrm{DME}$ & 2.5 & 2.67 & 2.56 & 96.1 \\
$\mathrm{DME}$ & 2.8 & 2.65 & 2.56 & 96.8 \\
$\mathrm{DME}$ & 3.2 & 2.64 & 2.51 & 95.4 \\
$\mathrm{DME}$ & -2.5 & 2.16 & 2.14 & 99.3 \\
$\mathrm{DME}$ & -2.8 & 2.80 & 2.78 & 99.3 \\
$\mathrm{DME}$ & -3.2 & 3.54 & 3.41 & 96.4 \\
$\mathrm{MeCN}$ & 2.2 & 1.74 & 1.62 & 93.9 \\
$\mathrm{MeCN}$ & 2.8 & 2.34 & 2.07 & 88.3 \\
$\mathrm{MeCN}$ & -2.0 & 1.80 & 1.75 & 97.6 \\
$\mathrm{MeCN}$ & -2.8 & 2.35 & 2.10 & 89.4
\end{tabular}

${ }^{a_{T}}$ The theoretical capacities are 2.68 and $5.36 \mathrm{~A} \mathrm{~h} \mathrm{~L}^{-1}$ for one and two sets of one-electron transitions, respectively. ${ }^{b}$ Values are averages over 100 cycles.

presence of a $\mathrm{C} \equiv \mathrm{N}$ triple bond, resulting in capacity loss. ${ }^{55}$ This is also evident from the observation of additional plateaus in the capacity-voltage profiles of the later cycles of the $\mathrm{MeCN}$ electrolytes (Figure S15). In general, the electrolytes show better cycling performance in the role of the catholyte as opposed to the anolyte, which is reflected in the capacity fading and the Coulombic efficiency (Table 3).

The most promising cell, that is, the one with as electrolyte $0.1 \mathrm{~mol} \mathrm{~L}^{-1}$ Me-TEG-DAAQ and $1 \mathrm{~mol} \mathrm{~L}^{-1}$ TEATf $_{2} \mathrm{~N}$ in DME, cycled between -2.8 and $0.0 \mathrm{~V}$ showed an average charge and discharge capacity of 2.80 and $2.78 \mathrm{~A} \mathrm{~h} \mathrm{~L} \mathrm{~L}^{-1}$, respectively, and an average Coulombic efficiency of $99.3 \%$ (Table 3). This cell was also cycled with a slightly less negative cut-off potential of $-2.5 \mathrm{~V}$ (Figure S16). At this milder cut-off potential, a decrease of the charge and discharge capacity was observed in the first cycles, but toward the end of the experiment, a stable plateau was reached at approx. $2.40 \mathrm{~A} \mathrm{~h}$ $\mathrm{L}^{-1}$, without a negative trend. The average Coulombic efficiency over 100 cycles was $99.3 \%$. Thus, narrowing the potential window of operation of the cell will result in higher long-term stability but at the cost of capacity. In this regard, cycling experiments with higher cut-off potentials were conducted as well. By broadening the potential window of operation of the cell, the second set of redox reactions (Red2 and $\mathrm{O} \times 2$ ) are accessible as well, which increases the theoretical capacity by a factor of 2 and the theoretical energy density by a factor of 2.5 (eq 1). The applied cut-off potentials were +2.8 and $-2.8 \mathrm{~V}$ for the MeCN electrolytes in the anolyte and catholyte mode, respectively, and +3.2 and $-3.2 \mathrm{~V}$ for the DME electrolytes (Figure 7). The corresponding capacityvoltage profiles of selected cycles can be found in the Supporting Information (Figure S17).

Similar to the cycling experiments at milder cut-off potentials, the initial capacities were high and approached the theoretical value of $5.36 \mathrm{~A} \mathrm{~h} \mathrm{~L}^{-1}$, considering both sets of redox couples. However, upon continued cycling, the reached charge and discharge capacities faded at a high rate. The cells in the catholyte mode reached a temporary plateau in capacity before eventually continuing to fade below the one-electron theoretical capacity. The capacity fading of the $\mathrm{MeCN}$ electrolytes occurred at a higher rate than the DME electrolytes, again showing poor chemical stability. This is also reflected in the Coulombic efficiencies, which decrease below $90 \%$ for the $\mathrm{MeCN}$ electrolytes but remain above $95 \%$ for the DME electrolytes.

Comparison with Other Redox Flow Batteries. In general, the reported symmetric RFB using Me-TEG-DAAQ as redox-active species offers many advantages compared to the state-of-the-art batteries (i.e., aqueous vanadium flow battery) and other reported examples (Table 4).

(1) Organic electrolytes containing Me-TEG-DAAQ are noncorrosive, as opposed to acidic and/or oxidizing aqueous electrolytes. (2) A RFB using Me-TEG-DAAQ does not rely on toxic and/or scarce heavy metal elements. (3) Me-TEGDAAQ can be synthesized in high yield from inexpensive precursors in relatively few steps. This compares favorably to many artificial bipolar molecules or biredox ionic liquids, where two different redox-active moieties are combined in one compound. $^{61,62}$ (4) A RFB using Me-TEG-DAAQ can achieve a cell potential of $2.7 \mathrm{~V}$, which far exceeds the cell potential of any aqueous RFB. Thus, the energy density can be higher at the same concentration of redox-active species (eq 1). As we have shown, it is possible to prepare electrolytes containing 1$2 \mathrm{~mol} \mathrm{~L}^{-1}$ Me-TEG-DAAQ resulting in energy densities of 49-98 $\mathrm{W} \mathrm{h} \mathrm{L}^{-1}$ for the two inner redox couples, and 122-245 $\mathrm{W} \mathrm{h} \mathrm{L}{ }^{-1}$ for the two sets of redox couples. This is much higher than VRBs that are currently available in the market (15-25 W $\mathrm{h} \mathrm{L}^{-1}$ ), even taking into account recent improvements using 

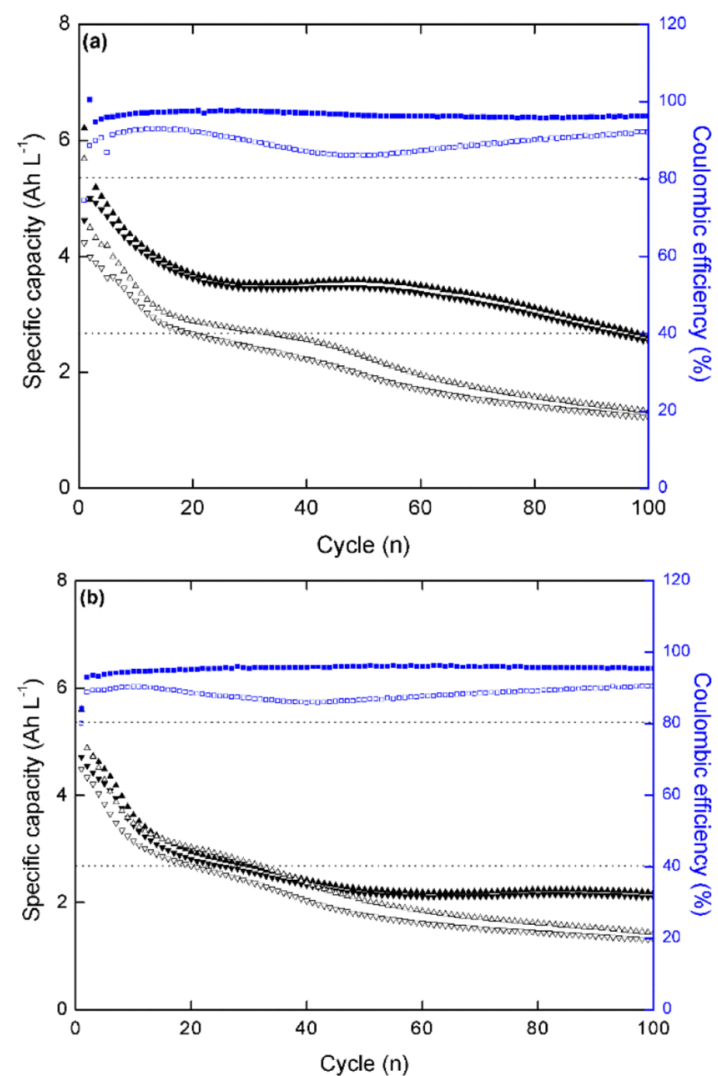

Figure 7. Charge capacities (upward triangles), discharge capacities (downward triangles), and Coulombic efficiencies (squares) over 100 cycles of $0.1 \mathrm{~mol} \mathrm{~L}^{-1} \mathrm{Me}-\mathrm{TEG}-\mathrm{DAAQ}$ and $1 \mathrm{~mol} \mathrm{~L}^{-1} \mathrm{TEATf}_{2} \mathrm{~N}$ in DME (full symbols) and MeCN (hollow symbols), used as the catholyte (a) or anolyte (b). The dotted lines denote the theoretical capacity for one set $\left(2.68 \mathrm{~A} \mathrm{~h} \mathrm{~L}^{-1}\right)$ and two sets $\left(5.36 \mathrm{~A} \mathrm{~h} \mathrm{~L}^{-1}\right)$ of one-electron transitions. The current density was +0.21 or $-0.21 \mathrm{~A}$ $\mathrm{dm}^{-2}$. precipitation inhibitors that can result in a 60-90\% increase in energy density, up to $48 \mathrm{~W} \mathrm{~h} \mathrm{~L}^{-1} .^{15}$ (5) To our knowledge, Me-TEG-DAAQ is the only compound that can be used as the sole redox-active species in a true symmetric flow cell (i.e., where all the redox couples are dissolved in the electrolytes) with such a high cell potential and at such high concentrations. Some other reported highly soluble redox-active molecules have only one redox transition and are combined with a solid lithium metal anode in a hybrid flow cell to achieve high cell potential and energy density. ${ }^{39,45}$ Another recently reported nonaqueous flow battery promises an achievable energy density of $223 \mathrm{~W} \mathrm{~h} \mathrm{~L}^{-1}$ but uses two different organic redox couples. ${ }^{60}$ This work is also a clear improvement over the work reported by Potash et al., as DB-134 saturated at a concentration of only $0.1 \mathrm{~mol} \mathrm{~L}^{-1}$ in their used cycling electrolyte, resulting in a maximum achievable energy density of only $12 \mathrm{~W} \mathrm{~h} \mathrm{~L}^{-1}$.

\section{CONCLUSIONS}

A promising redox-active molecule is reported for use in symmetric nonaqueous RFBs. This molecule, Me-TEGDAAQ was synthesized in high yield from precursors that are either commercially available at low cost or can be inexpensively prepared in a large scale. Me-TEG-DAAQ has five accessible reversible redox states that are typical for DAAQs while also overcoming the main disadvantage of the previously reported examples of this class of molecules, namely, the low solubility in polar organic solvents. MeTEG-DAAQ is fully miscible with $\mathrm{MeCN}$ and DME, easily achieving concentrations of more than $1 \mathrm{~mol} \mathrm{~L}^{-1}$, even when high concentrations of supporting electrolyte salts are present. Proof-of-concept cycling studies show the importance of the appropriate supporting electrolyte choice. Electrolytes consisting of $1 \mathrm{~mol} \mathrm{~L}^{-1} \mathrm{TEATf}_{2} \mathrm{~N}$ in $\mathrm{MeCN}$ have superior conductivity compared to the DME-based electrolytes, resulting in a smaller voltage drop over the membrane.

\section{Table 4. Battery Performance of Reported Aqueous and NonAqueous Flow Cells ${ }^{a}$}

\begin{tabular}{|c|c|c|c|c|c|c|c|}
\hline $\begin{array}{l}\text { anode } \| \text { cathode supporting } \\
\text { electrolyte }\end{array}$ & separator & 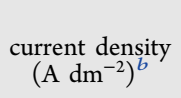 & $\begin{array}{c}\text { cell } \\
\text { potential } \\
(\mathrm{V})^{b}\end{array}$ & $\begin{array}{l}\text { energy density } \\
\left(\mathrm{Wh} \mathrm{L}^{-1}\right)^{b}\end{array}$ & $\begin{array}{l}\text { achievable energy } \\
\text { density (W h L }\end{array}$ & cycles $^{b}$ & references \\
\hline $\begin{array}{l}\text { vanadium ions symmetric } \\
\mathrm{H}_{2} \mathrm{SO}_{4(\mathrm{aq})}\end{array}$ & Nafion PEM & $8-20$ & 1.4 & $15-25$ & $24-48($ ref 15$)$ & $12,000-20,000$ & 56 \\
\hline $\mathrm{AQDS} \| \mathrm{Br}_{2} \mathrm{HBr}_{(\mathrm{aq})} / \mathrm{H}_{2} \mathrm{SO}_{4(\mathrm{aq})}$ & Nafion PEM & $20-50$ & 0.9 & 27 & $>50$ & 20 & 57 \\
\hline BQDS\|AQDS $\mathrm{H}_{2} \mathrm{SO}_{4(\mathrm{aq})}$ & Nafion PEM & 8 & 0.7 & 4 & $52^{c}$ & 20 & 58 \\
\hline $\begin{array}{l}\text { viologen } \| \text { TEMPO polymer } \\
\mathrm{NaCl}_{(\mathrm{aq})}\end{array}$ & $\begin{array}{l}\text { dialysis } \\
\text { membrane }\end{array}$ & $4-10$ & 1.1 & 10 & & 10,000 & 59 \\
\hline $\mathrm{Li} \| \mathrm{TEMPO} \mathrm{LiPF}_{6} / \mathrm{MC}$ & PE separator & $0.1-1$ & 3.5 & $64-126$ & & 100 & 39 \\
\hline $\mathrm{Li} \| 15 \mathrm{D} 3 \mathrm{GAQ} \mathrm{LiPF}_{6} / \mathrm{PC}$ & PP separator & $0.01-1$ & 2.5 & 32 & & 9 & 45 \\
\hline $\begin{array}{l}\text { MEEPT symmetric } \\
\text { TEABF }_{4} / \mathrm{MeCN}^{-}\end{array}$ & PP separator & $0.5-1.3$ & 0.4 & 6 & $12^{c}$ & 100 & 42 \\
\hline $\begin{array}{l}\text { 2-MBP } \text { TEAPBMM }_{6} / \mathrm{MeCN}^{-}\end{array}$ & PP separator & 0.75 & 3.0 & 4 & 223 & 50 & 60 \\
\hline $\begin{array}{l}\text { DB-134 symmetric } \\
\text { TBAClO }_{4} / \mathrm{MeCN} / \text { toluene }\end{array}$ & glass frit & & 2.7 & 6 & $12^{c}$ & 6 & 47 \\
\hline \multirow[t]{2}{*}{$\begin{array}{l}\text { Me-TEG-DAAQ symmetric } \\
\text { TEATf }_{2} \text { N/DME }\end{array}$} & Nafion PEM & 0.2 & 1.8 & 5 & $49-98^{d}$ & 100 & this work \\
\hline & Nafion PEM & 0.2 & 2.7 & 12 & $122-245^{e}$ & 100 & \\
\hline
\end{tabular}

${ }^{a}$ AQDS = anthraquinone disulfonic acid, BQDS = benzoquinone disulfonic acid, 15D3GAQ = 1,5-bis(2-(2-(2-methoxyethoxy)ethoxy)ethoxy)anthraquinone, MEEPT $=\mathrm{N}$-(2-(2-methoxyethoxy)ethyl)-phenothiazine, 2-MBP $=2$-methylbenzophenone, DBMMB $=2,5$-di-tert-butyl-1methoxy-4-[2'-methoxyethoxy]benzene, $\mathrm{MC}=$ mixed carbonates, $\mathrm{PC}=$ propylene carbonate, $\mathrm{PEM}=$ proton exchange membrane, $\mathrm{PE}=$ polyethylene, and PP = polypropylene. ${ }^{b}$ Based on experimentally reported data. ${ }^{c}$ Calculated from solubility data of the redox-active compounds, if available. ${ }^{d}$ Calculated for a cell utilizing the two inner redox couples, and for electrolyte concentrations of $1-2 \mathrm{~mol} \mathrm{~L}^{-1}$. ${ }^{e} \mathrm{Calculated}$ for a cell utilizing both sets of redox couples, and for electrolyte concentrations of $1-2 \mathrm{~mol} \mathrm{~L}^{-1}$. 
However, capacity fading in these electrolytes is much more prominent, which can be attributed to side reactions of the reduced and oxidized radical DAAQ species with the $\mathrm{C} \equiv \mathrm{N}$ triple bond in acetonitrile. DME is much less susceptible to such reactions and shows good capacity retention over 100 cycles for the inner redox couples. The outer redox couples are generally less reversible, and severe capacity fading is observed in both $\mathrm{DME}$ and $\mathrm{MeCN}$ electrolytes. Nevertheless, this system is very promising, as it is symmetrical and high capacities, large cell potentials, and good reversibility can be achieved under the right conditions. The theoretical energy densities exceed $49 \mathrm{~W} \mathrm{~h} \mathrm{~L}^{-1}$ for the inner redox couples and $122 \mathrm{~W} \mathrm{~h} \mathrm{~L}^{-1}$ for the two sets of redox couples. Of course, achieving these values will require considerations on slower kinetics because of increased electrolyte viscosity. However, we are convinced that this system can still be considerably improved by further optimization of the electrolyte composition, the membrane/separator and the cell component/design.

\section{ASSOCIATED CONTENT}

\section{SI Supporting Information}

The Supporting Information is available free of charge at https://pubs.acs.org/doi/10.1021/acssuschemeng.9b07244.

Synthesis of $\operatorname{TEATf}_{2} \mathrm{~N}$, calculations of diffusion coefficients and electron transfer rate constants, ${ }^{1} \mathrm{H}$ and ${ }^{13} \mathrm{C}$ NMR spectra of Me-TEG-DAAQ TLC experiment, optical absorption spectra of Me-TEGDAAQ in MeCN and DME, optical absorption spectra of Me-TEG-DAAQ standards, UV-vis standard calibration curves, reduction and oxidation mechanisms of DAAQs, CVs of Me-TEG-DAAQ and DB-134 in different solvent systems and at various scan rates, capacity-voltage profiles of cycling experiments of different electrolytes, and extra cycling experiment of a static symmetric cell at $-2.5 \mathrm{~V}$ cut-off potential (PDF)

\section{AUTHOR INFORMATION}

\section{Corresponding Author}

Koen Binnemans - Department of Chemistry, KU Leuven, B3001 Leuven, Belgium; 이이이.org/0000-0003-4768-3606; Email: Koen.Binnemans@kuleuven.be

\section{Authors}

Pieter Geysens - Department of Chemistry, KU Leuven, B3001 Leuven, Belgium; 이이. ord/0000-0002-8846-7777

Yun Li - Department of Microbial and Molecular Systems, KU Leuven, B-3001 Leuven, Belgium

Ivo Vankelecom - Department of Microbial and Molecular Systems, KU Leuven, B-3001 Leuven, Belgium; 이이.org/ 0000-0002-0104-9493

Jan Fransaer - Department of Materials Engineering, KU Leuven, B-3001 Leuven, Belgium

Complete contact information is available at: https://pubs.acs.org/10.1021/acssuschemeng.9b07244

\section{Notes}

The authors declare no competing financial interest.

\section{ACKNOWLEDGMENTS}

The authors thank the KU Leuven for financial support (project KP/14/005) and Jorik Evers for his assistance with synthesis and characterization. Y.L. thanks the FWO Flanders for a postdoctoral fellowship.

\section{REFERENCES}

(1) Gyuk, I.; Johnson, M.; Vetrano, J.; Lynn, K.; Parks, W.; Handa, R.; Kannberg, L.; Hearne, S.; Waldrip, K.; Braccio, R. Grid Energy Storage. [online]; US Department of Energy: Washington DC, US, 2013, https://www.energy.gov/sites/prod/files/2014/09/f18/ GridEnergyStorageDecember2013.pdf (accessed Jan 21, 2019).

(2) Hoffert, M. I.; Caldeira, K.; Benford, G.; Criswell, D. R.; Green, C.; Herzog, H.; Jain, A. K.; Kheshgi, H. S.; Lackner, K. S.; Lewis, J. S.; Lightfoot, H. D.; Manheimer, W.; Mankins, J. C.; Mauel, M. E.; Perkins, L. J.; Schlesinger, M. E.; Volk, T.; Wigley, T. M. L. Advanced Technology Paths to Global Climate Stability: Energy for a Greenhouse Planet. Science 2002, 298, 981.

(3) Denholm, P.; Ela, E.; Kirby, B.; Milligan, M. The Role of Energy Storage with Renewable Electricity Generation; National Renewable Energy Laboratory/TP-6A2-47187, 2010, https://www.nrel.gov/ docs/fy10osti/47187.pdf (accessed Jan 22, 2019).

(4) Lewis, N. S.; Nocera, D. G. Powering the planet: Chemical challenges in solar energy utilization. Proc. Natl. Acad. Sci. U.S.A. 2006, 103, 15729-15735.

(5) Yang, Z.; Zhang, J.; Kintner-Meyer, M. C. W.; Lu, X.; Choi, D.; Lemmon, J. P.; Liu, J. Electrochemical energy storage for green grid. Chem. Rev. 2011, 111, 3577-3613.

(6) Dunn, B.; Kamath, H.; Tarascon, J.-M. Electrical energy storage for the grid: A battery of choices. Science 2011, 334, 928-935.

(7) Bartolozzi, M. Development of redox flow batteries: A historical bibliography. J. Power Sources 1989, 27, 219-234.

(8) Ponce de León, C.; Frías-Ferrer, A.; González-García, J.; Szánto, D. A.; Walsh, F. C. Redox flow cells for energy conversion. J. Power Sources 2006, 160, 716-732.

(9) Weber, A. Z.; Mench, M. M.; Meyers, J. P.; Ross, P. N.; Gostick, J. T.; Liu, Q. Redox flow batteries: A review. J. Appl. Electrochem. 2011, 41, 1137-1164.

(10) Leung, P.; Li, X.; Ponce de León, C.; Berlouis, L.; Low, C. T. J.; Walsh, F. C. Progress in redox flow batteries, remaining challenges and their applications in energy storage. RSC Adv. 2012, 2, 1012510156.

(11) Alotto, P.; Guarnieri, M.; Moro, F. Redox flow batteries for the storage of renewable energy: A review. Renewable Sustainable Energy Rev. 2014, 29, 325-335.

(12) Wang, W.; Nie, Z.; Chen, B.; Chen, F.; Luo, Q.; Wei, X.; Xia, G.-G.; Skyllas-Kazacos, M.; Li, L.; Yang, Z. A new Fe/V redox flow battery using a sulfuric/chloric mixed acid supporting electrolyte. $A d v$. Energy Mater. 2012, 2, 487-493.

(13) Skyllas-Kazacos, M.; Rychcik, M.; Robins, R. G.; Fane, A. G.; Green, M. A. New all-vanadium redox flow cell. J. Electrochem. Soc. 1986, 133, 1057-1058.

(14) Vijayakumar, M.; Wang, W.; Nie, Z.; Sprenkle, V.; Hu, J. Elucidating the higher stability of vanadium $(\mathrm{V})$ cations in mixed acid based redox flow battery electrolytes. J. Power Sources 2013, 241, 173-177.

(15) Roe, S.; Menictas, C.; Skyllas-Kazacos, M. A high energy density vanadium redox flow battery with $3 \mathrm{M}$ vanadium electrolyte. $J$. Electrochem. Soc. 2016, 163, A5023-A5028.

(16) Li, X.; Zhang, H.; Mai, Z.; Zhang, H.; Vankelecom, I. Ion exchange membranes for vanadium redox flow battery (VRB) applications. Energy Environ. Sci. 2011, 4, 1147-1160.

(17) Shin, S.-H.; Yun, S.-H.; Moon, S.-H. A review of current developments in non-aqueous redox flow batteries: characterization of their membranes for design perspective. RSC Adv. 2013, 3, 90959116.

(18) Wang, W.; Luo, Q.; Li, B.; Wei, X.; Li, L.; Yang, Z. Recent progress in redox flow battery research and development. Adv. Funct. Mater. 2013, 23, 970-986.

(19) Wang, W.; Sprenkle, V. Redox flow batteries go organic. Nat. Chem. 2016, 8, 204-206. 
(20) Perry, M. L.; Weber, A. Z. Advanced redox-flow batteries: A perspective. J. Electrochem. Soc. 2016, 163, A5064-A5067.

(21) Lloyd, D.; Vainikka, T.; Kontturi, K. The development of an all copper hybrid redox flow battery using deep eutectic solvents. Electrochim. Acta 2013, 100, 18-23.

(22) Zhang, C.; Qian, Y.; Ding, Y.; Zhang, L.; Guo, X.; Zhao, Y.; Yu, G. Biredox eutectic electrolytes derived from organic redox-active molecules: High-energy storage systems. Angew. Chem., Int. Ed. 2019, 58, 7045-7050

(23) Pleskov, Y. V. Nonaqueous Electrochemistry Edited by D. Aurbach. Russ. J. Electrochem. 2001, 37, 871-872.

(24) Hayyan, M.; Mjalli, F. S.; Hashim, M. A.; AlNashef, I. M.; Mei, T. X. Investigating the electrochemical windows of ionic liquids. J. Ind. Eng. Chem. 2013, 19, 106-112.

(25) Buzzeo, M. C.; Hardacre, C.; Compton, R. G. Extended electrochemical windows made accessible by room temperature ionic liquid-organic solvent electrolyte systems. ChemPhysChem 2006, 7, 176-180.

(26) Matsuda, Y.; Tanaka, K.; Okada, M.; Takasu, Y.; Morita, M.; Matsumura-Inoue, T. A rechargeable redox battery utilizing ruthenium complexes with non-aqueous organic electrolyte. J. Appl. Electrochem. 1988, 18, 909-914.

(27) Chakrabarti, M. H.; Roberts, E. P. L.; Bae, C.; Saleem, M. Ruthenium based redox flow battery for solar energy storage. Energy Convers. Manage. 2011, 52, 2501-2508.

(28) Escalante-García, I. L.; Wainright, J. S.; Thompson, L. T.; Savinell, R. F. Performance of a non-aqueous vanadium acetylacetonate prototype redox flow battery: Examination of separators and capacity decay. J. Electrochem. Soc. 2015, 162, A363-A372.

(29) Laramie, S. M.; Milshtein, J. D.; Breault, T. M.; Brushett, F. R.; Thompson, L. T. Performance and cost characteristics of multielectron transfer, common ion exchange non-aqueous redox flow batteries. J. Power Sources 2016, 327, 681-692.

(30) Mun, J.; Lee, M.-J.; Park, J.-W.; Oh, D.-J.; Lee, D.-Y.; Doo, S.G. Non-aqueous redox flow batteries with nickel and iron tris $\left(2,2^{\prime}-\right.$ bipyridine) complex electrolyte. Electrochem. Solid-State Lett. 2012, 15, A80-A82.

(31) Ding, Y.; Zhao, Y.; Li, Y.; Goodenough, J. B.; Yu, G. A highperformance all-metallocene-based, non-aqueous redox flow battery. Energy Environ. Sci. 2017, 10, 491-497.

(32) Cabrera, P. J.; Yang, X.; Suttil, J. A.; Brooner, R. E. M.; Thompson, L. T.; Sanford, M. S. Evaluation of tris-bipyridine chromium complexes for flow battery applications: Impact of bipyridine ligand structure on solubility and electrochemistry. Inorg. Chem. 2015, 54, 10214-10223.

(33) Liu, Q.; Shinkle, A. A.; Li, Y.; Monroe, C. W.; Thompson, L. T.; Sleightholme, A. E. S. Nonaqueous chromium acetylacetonate electrolyte for redox flow batteries. Electrochem. Commun. 2010, 12, 1634-1637.

(34) Xing, X.; Zhang, D.; Li, Y. A non-aqueous all-cobalt redox flow battery using 1,10-phenanthrolinecobalt(II) hexafluorophosphate as active species. J. Power Sources 2015, 279, 205-209.

(35) Schaltin, S.; Li, Y.; Brooks, N. R.; Sniekers, J.; Vankelecom, I. F. J.; Binnemans, K.; Fransaer, J. Towards an all-copper redox flow battery based on a copper-containing ionic liquid. Chem. Commun. 2016, 52, 414-417.

(36) Li, Y.; Sniekers, J.; Malaquias, J.; Li, X.; Schaltin, S.; Stappers, L.; Binnemans, K.; Fransaer, J.; Vankelecom, I. F. J. A non-aqueous all-copper redox flow battery with highly soluble active species. Electrochim. Acta 2017, 236, 116-121.

(37) Li, Z.; Li, S.; Liu, S.; Huang, K.; Fang, D.; Wang, F.; Peng, S. Electrochemical properties of an all-organic redox flow battery using 2,2,6,6-tetramethyl-1-piperidinyloxy and $\mathrm{N}$-methylphtalimide. Electrochem. Solid-State Lett. 2011, 14, A171-A173.

(38) Park, S.-K.; Shim, J.; Yang, J.; Shin, K.-H.; Jin, C.-S.; Lee, B. S.; Lee, Y.-S.; Jeon, J.-D. Electrochemical properties of a non-aqueous redox battery with all-organic redox couples. Electrochem. Commun. 2015, 59, 68-71.
(39) Wei, X.; Xu, W.; Vijayakumar, M.; Cosimbescu, L.; Liu, T.; Sprenkle, V.; Wang, W. TEMPO-based catholyte for high-energy density nonaqueous redox flow batteries. Adv. Mater. 2014, 26, 76497653.

(40) Milshtein, J. D.; Barton, J. L.; Darling, R. M.; Brushett, F. R. 4Acetamido-2,2,6,6-tetramethylpiperidine-1-oxyl as a model organic redox active compound. J. Power Sources 2016, 327, 151-159.

(41) Kaur, A. P.; Holubowitch, N. E.; Ergun, S.; Elliott, C. F.; Odom, S. A. A highly soluble organic catholyte for non-aqueous redox flow batteries. Energy Technol. 2015, 3, 476-480.

(42) Milshtein, J. D.; Kaur, A. P.; Casselman, M. D.; Kowalski, J. A.; Modekrutti, S.; Zhang, P. L.; Harsha Attanayake, N.; Elliott, C. F.; Parkin, S. R.; Risko, C.; Brushett, F. R.; Odom, S. A. High current density, long duration cycling of soluble organic active species for non-aqueous redox flow batteries. Energy Environ. Sci. 2016, 9, 35313543.

(43) Duan, W.; Vemuri, R. S.; Milshtein, J. D.; Laramie, S.; Dmello, R. D.; Huang, J.; Zhang, L.; Hu, D.; Vijayakumar, M.; Wang, W.; Liu, J.; Darling, R. M.; Thompson, L.; Smith, K.; Moore, J. S.; Brushett, F. R.; Wei, X. A symmetric organic-based nonaqueous redox flow battery and its state of charge diagnostics by FTIR. J. Mater. Chem. A 2016, 4, $5448-5456$

(44) Xing, X.; Huo, Y.; Wang, X.; Zhao, Y.; Li, Y. A benzophenonebased anolyte for high energy density all-organic redox flow battery. Int. J. Hydrogen Energy 2017, 42, 17488-17494.

(45) Wang, W.; Xu, W.; Cosimbescu, L.; Choi, D.; Li, L.; Yang, Z. Anthraquinone with tailored structure for a nonaqueous metalorganic redox flow battery. Chem. Commun. 2012, 48, 6669-6671.

(46) Huang, J.; Yang, Z.; Vijayakumar, M.; Duan, W.; Hollas, A.; Pan, B.; Wang, W.; Wei, X.; Zhang, L. A two-electron storage nonaqueous organic redox flow battery. Adv. Sustainable Syst. 2018, 2, 1700131-1700137.

(47) Potash, R. A.; McKone, J. R.; Conte, S.; Abruña, H. D. On the benefits of a symmetric redox flow battery. J. Electrochem. Soc. 2016, 163, A338-A344.

(48) Vatanen, V.; Pedersen, J. A. Electron paramagnetic resonance and cyclic voltammetry studies of the cations and anions of $\alpha$ aminoanthraquinones obtained by electrochemical oxidation/reduction. J. Chem. Soc., Perkin Trans. 2 1996, 2, 2207-2212.

(49) Murdock, K. C.; Child, R. G.; Fabio, P. F.; Angier, R. D.; Wallace, R. E.; Durr, F. E.; Citarella, R. V. Antitumor agents. 1. 1,4bis[(aminoalkyl)amino]-9,10-anthracenediones. J. Med. Chem. 1979, 22, 1024-1030.

(50) Gianoncelli, A.; Basili, S.; Scalabrin, M.; Sosic, A.; Moro, S.; Zagotto, G.; Palumbo, M.; Gresh, N.; Gatto, B. Rational design, synthesis, and DNA binding properties of novel sequence-selective peptidyl congeners of ametantrone. ChemMedChem 2010, 5, 10801091.

(51) Komáromy, D.; Stuart, M. C. A.; Monreal Santiago, G.; Tezcan, M.; Krasnikov, V. V.; Otto, S. Self-assembly can direct covalent bond formation towards diversity or specificity. J. Am. Chem. Soc. 2017, 139, 6234-6241.

(52) Toupance, T.; Bassoul, P.; Mineau, L.; Simon, J. Poly(oxyethylene)-substituted copper and lutetium phthalocyanines. $J$. Phys. Chem. 1996, 100, 11704-11710.

(53) McKeown, N. B.; Painter, J. Lyotropic and thermotropic mesophase formation of novel tetra-[oligo(ethyleneoxy)]-substituted phthalocyanines. J. Mater. Chem. 1994, 4, 1153-1156.

(54) Wei, X.; Xu, W.; Huang, J.; Zhang, L.; Walter, E.; Lawrence, C.; Vijayakumar, M.; Henderson, W. A.; Liu, T.; Cosimbescu, L.; Li, B.; Sprenkle, V.; Wang, W. Radical compatibility with nonaqueous electrolytes and its impact on an all-organic redox flow battery. Angew. Chem., Int. Ed. 2015, 54, 8684-8687.

(55) Armstrong, C. G.; Toghill, K. E. Stability of molecular radicals in organic non-aqueous redox flow batteries: A mini review. Electrochem. Commun. 2018, 91, 19-24.

(56) Ding, C.; Zhang, H.; Li, X.; Liu, T.; Xing, F. Vanadium flow battery for energy storage: Prospects and challenges. J. Phys. Chem. Lett. 2013, 4, 1281-1294. 
(57) Huskinson, B.; Marshak, M. P.; Suh, C.; Er, S.; Gerhardt, M. R.; Galvin, C. J.; Chen, X.; Aspuru-Guzik, A.; Gordon, R. G.; Aziz, M. J. A metal-free organic-inorganic aqueous flow battery. Nature 2014, 505, 195-198.

(58) Yang, B.; Hoober-Burkhardt, L.; Krishnamoorthy, S.; Murali, A.; Prakash, G. K. S.; Narayanan, S. R. High-performance aqueous organic flow battery with quinone-based redox couples at both electrodes. J. Electrochem. Soc. 2016, 163, A1442-A1449.

(59) Janoschka, T.; Martin, N.; Martin, U.; Friebe, C.; Morgenstern, S.; Hiller, H.; Hager, M. D.; Schubert, U. S. An aqueous, polymerbased redox-flow battery using non-corrosive, safe, and low-cost materials. Nature 2015, 527, 78-81.

(60) Xing, X.; Liu, Q.; Xu, W.; Liang, W.; Liu, J.; Wang, B.; Lemmon, J. P. All-liquid electroactive materials for high energy density organic flow battery. ACS Appl. Energy Mater. 2019, 2, 23642369.

(61) Janoschka, T.; Friebe, C.; Hager, M. D.; Martin, N.; Schubert, U. S. An approach toward replacing vanadium: A single organic molecule for the anode and cathode of an aqueous redox-flow battery. ChemistryOpen 2017, 6, 216-220.

(62) Mourad, E.; Coustan, L.; Freunberger, S. A.; Mehdi, A.; Vioux, A.; Favier, F.; Fontaine, O. Biredox ionic liquids: electrochemical investigation and impact of ion size on electron transfer. Electrochim. Acta 2016, 206, 513-523. 